\title{
Nanomaterials and Essential Oils as Candidates for Developing Novel Treatment Options for Bovine Mastitis
}

\author{
Andra Sabina Neculai-Valeanu ${ }^{1, *} \mathbb{C}$, Adina Mirela Ariton ${ }^{1,2}$, Bianca Maria Mădescu ${ }^{1,2}$, Cristina Mihaela Rîmbu ${ }^{3}$ \\ and Şteofil Creanga ${ }^{2}$ \\ 1 Research and Development Station for Cattle Breeding Dancu, Sos. Iasi-Ungheni no. 9, \\ 707252 Dancu, Romania; mirela.ariton@scdb-dancu.ro (A.M.A.); biancamadescu@uaiasi.ro (B.M.M.) \\ 2 Department of Fundamental Sciences in Animal Husbandry, Faculty of Food and Animal Sciences, \\ Iasi University of Life Sciences (IULS), Mihail Sadoveanu Alley no. 8, 700490 Iasi, Romania; \\ screanga@uaiasi.ro \\ 3 Department of Public Health, Faculty of Veterinary Medicine, Iasi University of Life Sciences (IULS), \\ Mihail Sadoveanu Alley no. 8,700490 Iasi, Romania; crimbu@uaiasi.ro \\ * Correspondence: sabina.valeanu@scdb-dancu.ro
}

Citation: Neculai-Valeanu, A.S.; Ariton, A.M.; Mădescu, B.M.; Rîmbu, C.M.; Creangă, Ş. Nanomaterials and Essential Oils as Candidates for Developing Novel Treatment Options for Bovine Mastitis. Animals 2021, 11, 1625. https://doi.org/10.3390/ ani11061625

Academic Editor: Valerie E. Ryman

Received: 26 April 2021

Accepted: 26 May 2021

Published: 31 May 2021

Publisher's Note: MDPI stays neutral with regard to jurisdictional claims in published maps and institutional affiliations.

Copyright: (c) 2021 by the authors. Licensee MDPI, Basel, Switzerland. This article is an open access article distributed under the terms and conditions of the Creative Commons Attribution (CC BY) license (https:/ / creativecommons.org/licenses/by/ $4.0 /)$.
Simple Summary: Bovine mastitis is a highly prevalent and expensive illness that leads to enormous financial losses to dairy industries. Although significant progress has been made in the control and therapy of mastitis, the frequency of this disease continues to be high in livestock herds, having a negative influence on productive parameters and implicitly on economic indices in dairy farms. The opportunity to address this problem resides in the fact that a countries' share of the community market will only be maintained by increasing milk quality. It is imperative for cattle farmers, milk producers and national economies to obtain milk according to EU standards, in order for it to be valued at advantageous, competitive prices. This objective may be achieved by keeping the incidence of mastitis under very strict control, using novel treatment options.

Abstract: Nanomaterials have been used for diagnosis and therapy in the human medical field, while their application in veterinary medicine and animal production is still relatively new. Nanotechnology, however, is a rapidly growing field, offering the possibility of manufacturing new materials at the nanoscale level, with the formidable potential to revolutionize the agri-food sector by offering novel treatment options for prevalent and expensive illnesses such as bovine mastitis. Since current treatments are becoming progressively more ineffective in resistant bacteria, the development of innovative products based on both nanotechnology and phytotherapy may directly address a major global problem, antimicrobial resistance, while providing a sustainable animal health solution that supports the production of safe and high-quality food products. This review summarizes the challenges encountered presently in the treatment of bovine mastitis, emphasizing the possibility of using new-generation nanomaterials (e.g., biological synthesized nanoparticles and graphene) and essential oils, as candidates for developing novel treatment options for bovine mastitis.

Keywords: antimicrobial resistance; cattle; essential oils; graphene; mastitis; nanoparticles

\section{Introduction}

The livestock industry is presently centered on the genetic improvement of dairy cattle, with the increase in yield milk being nearly double compared to 1960 [1]. The dairy sector accounts today for around $15 \%$ of the total agricultural output. However, selecting for a higher yield of milk production is correlated with the appearance of certain problems in the udders of dairy cows, such as higher percentage of somatic cells and a higher incidence of mastitis [2].

Bovine mastitis is the most prevalent and expensive illness affecting milk herds worldwide. The disease leads to enormous financial losses to dairy industries as a result of 
decreased milk production and quality, condemnation of milk due to antibiotic residues and culling of chronically infected cows, as well as associated therapy costs. When zoonotic pathogens are involved, mastitis may pose a serious health risk due to the dispersion of bacteria and toxins in milk.

In the clinical form, symptoms may vary depending on the causative agent, while in the subclinical form, there are no visible changes in the aspect of the udder or milk. Monitoring the number of somatic cells is a widely used practice in the European Union (EU) for assessing milk quality [3,4].

Although significant progress has been made in the control and therapy of mastitis, the frequency of this disease continues to be high in some livestock herds, having a negative influence on productive parameters and implicitly on economic indices in dairy farms. In Europe, the economic losses caused by mastitis to the dairy industry have been estimated at around 2 billion euros annually. A poll conducted in the major milk-producing countries indicates that this disease affects, each year, between $15 \%$ and $20 \%$ of the dairy cow population. Based on the origin of the pathogen, mastitis may be classified as environmental, caused by pathogens from the environment and contagious, spread from other infected quarters [5]. According to previously conducted studies, the most common bacteria causing intramammary inflammation are Staphylococcus aureus, Streptococcus agalactiae, Escherichia coli and Streptococcus uberis [6-8].

The opportunity to address this problem resides in the fact that a country's share of the community market will only be maintained by increasing milk quality. It is imperative for cattle farmers, milk producers, and national economies to obtain milk according to EU standards in order to value it at advantageous, competitive prices. This objective may be achieved by keeping the incidence of bovine mastitis under very strict control using novel treatment options [9].

By the end of 2027, the worldwide bovine mastitis market is expected to hit USD 1.84 billion. It is estimated that recent breakthroughs, such as nanomaterials-based solutions for the treatment and control of bovine mastitis, will lead the way to an interesting future of the global market. According to the report entitled "Bovine Mastitis Market Size, Share \& COVID-19 Impact analysis, by type (Clinical, and Sub-Clinical), by product (antibiotics, and others), by route of administration (Intra-mammary, and Systemic), by therapy (Lactating Period and Dry Period) and Regional Forecast, 2020-2027", published by Fortune Business Insights, the market, which was estimated in 2019 at USD 1.23 billion, is forecasted to experience a compound annual growth rate (CAGR) of 5.2\% during 2020-2027 [10]. The growth of the European market will be powered by a growing number of business alliances aimed at developing novel treatment options for bovine mastitis in a number of countries, including France, Germany and the UK.

Nanomaterials have been used for diagnosis and therapy in the human medical field, while their application in veterinary medicine, for drug delivery, diagnostic and cell sorting or antimicrobials [11-14] and animal production, especially animal nutrition [15-18], is still relatively new. Nanotechnology, however, is a rapidly growing field, offering the possibility of manufacturing new materials at the nanoscale level, with the formidable potential to revolutionize the agri-food sector by offering novel treatment options for prevalent and expensive illnesses such as bovine mastitis.

This review summarizes the challenges encountered presently in the treatment of bovine mastitis, emphasizing the possibility of using new-generation nanomaterials, such as biological synthesized nanoparticles and graphene, and essential oils as candidates for developing novel treatment options for bovine mastitis.

\section{Farm Model with "Low Antibiotic Consumption"}

Owing to inadequate monitoring and data collection in many nations, figures of overall annual global antibiotic use in the EU's agricultural sector vary greatly, from 1770.4 tonnes per year in Spain to 0.6. tones in Iceland [19]. The differences between countries are explained by a variety of factors. To begin with, animal populations, as well 
as production systems, differ considerably from one country to other. A second aspect is the dose and treatment period, which are not included in the results because there are significant differences across countries regarding the pharmaceutical formulations used and the length of the therapy. Different antibiotics, as well as different amounts, are needed depending on whether pigs, cows, sheep or chickens are treated. For this reason, one of the key points of the ESVAC: Vision, Strategy and Objectives for 2016-2020 was the development of a system for collecting harmonized and standardized data on antimicrobial use by animal species in order to conduct a more systematic study of patterns in antimicrobial use [20].

In 2017, the European Commission and the EMA held a workshop on the compilation of data on veterinary antimicrobial use in EU countries. Stakeholders were mostly in agreement on the importance of collecting data on antimicrobial use by animal species, as well as the advantages of doing so; therefore, on February 6th 2018, ESVAC adopted a guide regarding the collection and provision of national data on antimicrobial use by animal species/categories. Since the volume of veterinary antimicrobial agents sold across the EU member states is related to the animal population structure, in order to normalize the sales statistics for the animal population that may be treated with antimicrobial agents, the European Commission requested that the European Centre for Disease Prevention and Control (ECDC), European Food Safety Authority (EFSA) and European Medicines Agency (EMA) use a common scientific opinion regarding some indicators that may be used for the surveillance of antimicrobial resistance and antimicrobial consumption in humans and food-producing animals [21]. The European Surveillance of Veterinary Antimicrobial Consumption (ESVAC) employed a population correction unit (PCU) as a proxy for the size of the animal population [19] (Figure 1).



Figure 1. Estimated PCU (in 1000 tonnes) of the population of food-producing species (including horses) for 2018 in some EU member states according to the European database of sales of veterinary antimicrobial agents.

The proposed indicators used presently for antimicrobial surveillance are classified as primary indicators-overall sales of veterinary antimicrobials expressed in $\mathrm{mg} / \mathrm{PC}$ and secondary indicators - sales of 3rd- and 4th-generation cephalosporins in mg/PCU; sales of quinolones, specifying the $\%$ of fluoroquinolones in $\mathrm{mg} / \mathrm{PCU}$, and sales of polymyxins in $\mathrm{mg} / \mathrm{PCU}$ [21]. This format is considered more suitable for comparing sales data across countries and years because it accounts for variations in the size and composition of the animal population in the EU member states $[19,20]$.

Veterinarians, fishermen, other livestock industry players, EU Member States, the European Commission and the European Medicines Agency have all worked together to reduce sales of antimicrobials. National strategies for antibiotic stewardship in livestock, limitations regarding the use of certain antimicrobials in food-producing animals, the removal of antibiotics as growth promoters and EU good practices guidelines are among the measures taken to decrease veterinary antimicrobial purchases across Europe. These 
measures are part of the EU's One Health Action Plan to Tackle Antimicrobial Resistance (AMR). According to The European Medicines Agency (EMA), between 2011 and 2017, the total sales of veterinary antibiotics in Europe fell by more than $32 \%$ [22].

Antimicrobial resistance is a worldwide issue that affects all countries and populations, regardless of wealth or socioeconomic status, but the challenges are proportionally higher in underdeveloped countries and emergent economies [23]. Resistant organisms have no territorial or biological boundaries: they may quickly propagate by the migration of humans, plants, food or water, and certain resistance genes can be transferred from one species to another [9]. Apart from being a naturally occurring phenomenon, antimicrobial resistance occurs in both humans and animals when antibiotics are used excessively or inappropriately, subsequently leading to environmental pollution as well (Figure 2).

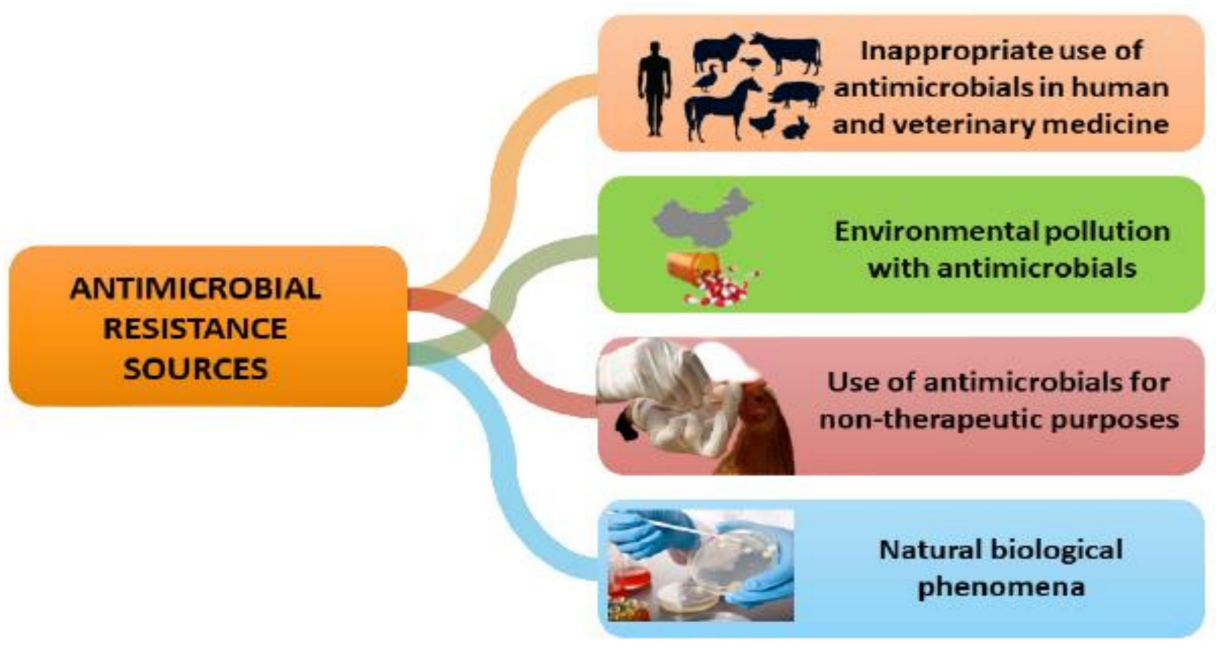

Figure 2. Main sources of antimicrobial resistance.

Studies conducted by various authors showed that sub-lethal antibiotic therapy may lead to multidrug resistance due to reactive oxygen species (ROS)-induced mutagenesis [24-27]. Moreover, a study conducted by Li et al. (2021) [28] in a simulated sublethal concentration of copper and tetracycline co-contaminated environment showed that the contamination of the environment with metals and antibiotics may accelerate the emergence of antibiotic-resistant bacteria and their dissemination.

Given the near interdependence between humans and animals that share the same ecosystem, excessive veterinary use of these compounds poses a potential public health threat $[29,30]$. For example, in Romania, the high consumption rates and the widespread use of broad-spectrum antibiotics for both human and animals has led to growing concerns over antimicrobial resistance. The country ranked 3rd among the EU countries for total consumption (community and hospital sector) of antibacterials for systemic use (ATC group J01) in 2019 [31] (Figure 3) and 12th regarding the use of antimicrobials for food-producing species (including horses), expressed in $\mathrm{mg}$ per population correction unit (mg/PCU), in 2018 (Figure 4) [22]

The situation raised the awareness of the European Public Health Alliance (EPHA), which subsequently commissioned a study regarding the current AMR situation in Romania. According to the conducted study, Romania is "in the red zone" due to inadequate multidisciplinary collaboration between clinicians, microbiologists and epidemiologists; the limited collaboration between human and veterinary domains with regard to AMR; and the lack of robust data regarding the infections with "superbugs" in both humans and animals. Unfortunately, several other EU member states are confronted with similar threats, which tend to affect Europe's safety network [32], thus becoming a growing cross-border threat to public health in Europe and around the world [33,34]. Antimicrobial-resistant infections are believed to kill 700,000 people per year around the world. If urgent actions are not taken, the number is expected to climb to 10 million people by 2050 , with associ- 
ated costs of $\$ 100$ trillion. Many of the Sustainable Development Goals (SDGs) are also compromised by AMR. The World Bank predicts that an additional 28 million people will be plunged into extreme poverty by 2050 if AMR is not regulated adequately [35-39].

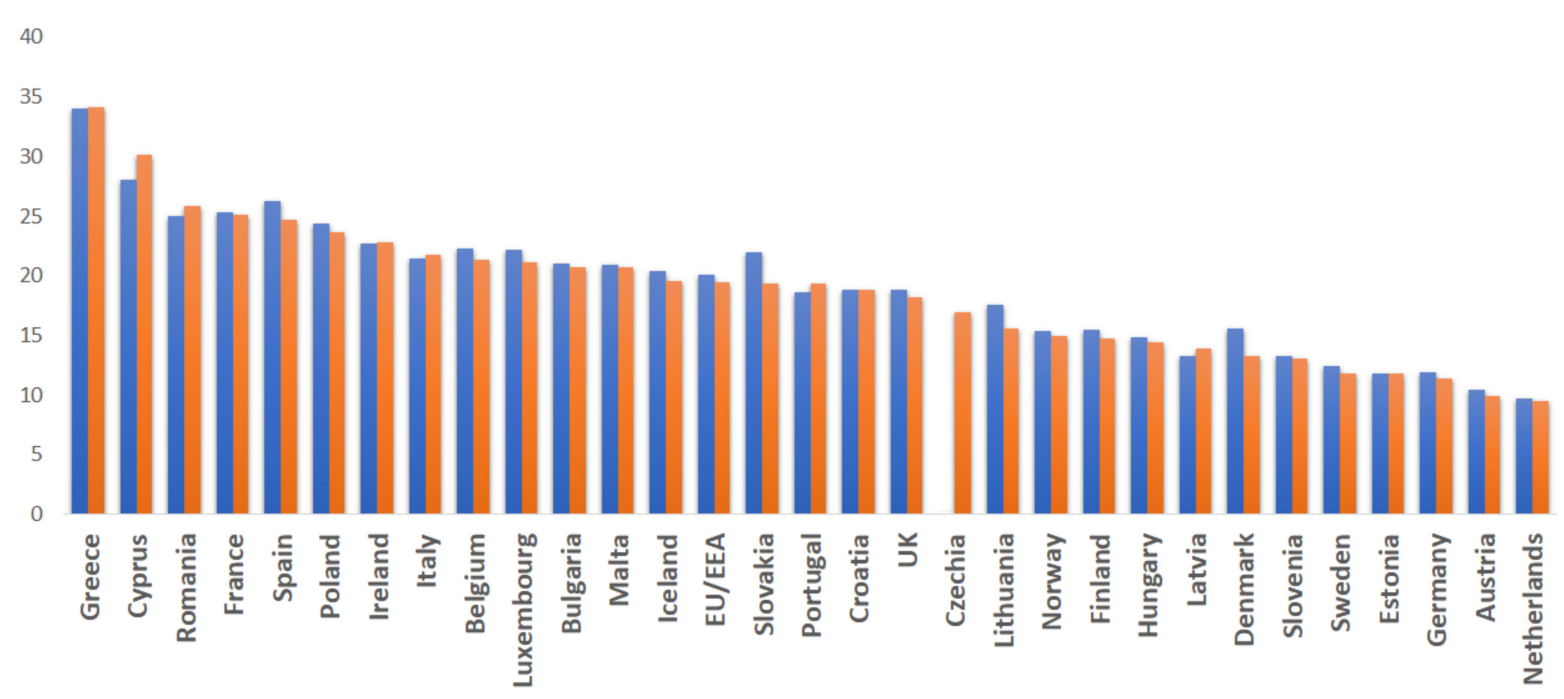

- $2018=2019$

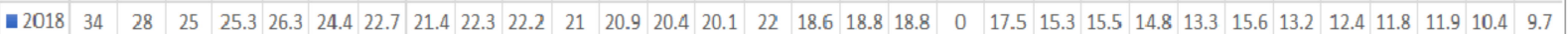

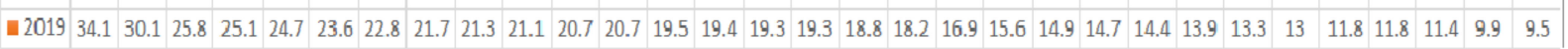

Figure 3. Total consumption (community and hospital sector) of antibacterials for systemic use (ATC group J01) by country, EU/EEA, 2018-2019 (expressed as DDD per 1000 inhabitants per day).

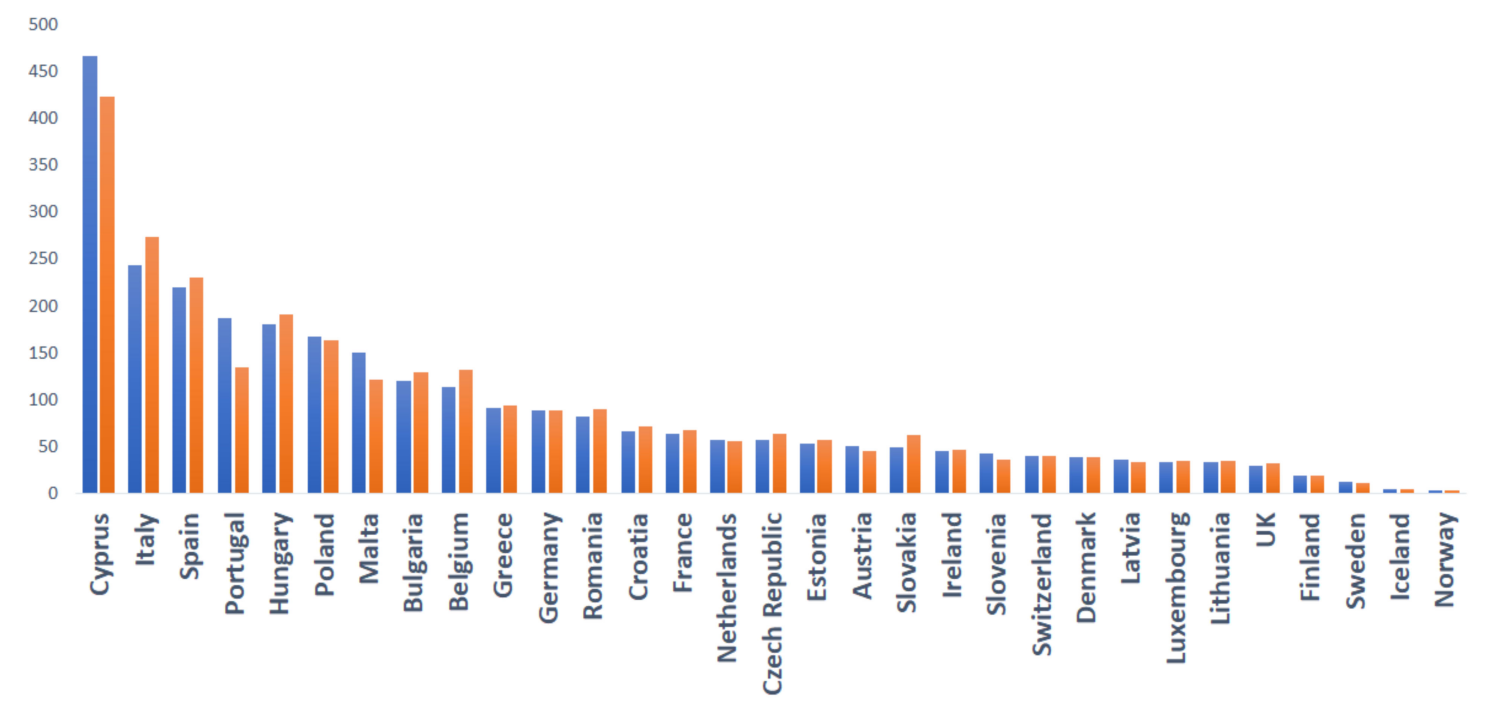

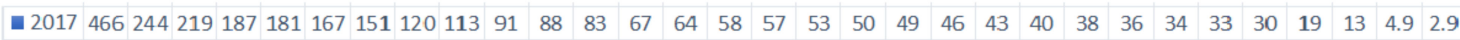

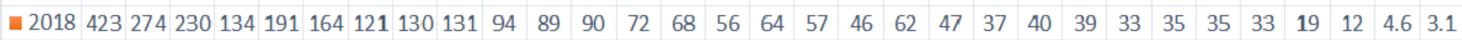

Figure 4. Overall sales for food-producing animals (including horses), in mg per population correction unit (mg/PCU), of the various veterinary antimicrobial classes, by country, for 2017 and 2018.

One of the specific objectives of the new Commune Agricultural Policy (CAP), after 2020, is to improve the response of EU agriculture to society's food and health demands. The European Commission's proposal for a new CAP contains several key points to support the transition towards a European farm model with "low antibiotic consumption". If successful, this will help to achieve the EU's vision of a region of "best practices" to counteract AMR, as stipulated in the Health Action Plan against AMR. The new policies represent an opportunity for the transition to high-health production systems that will 
provide healthy, more profitable livestock, improved financial results for farmers, and decreased antibiotic use [40-44].

Bovine mastitis is the most costly disease affecting cows worldwide. Reduced milk production, changes in milk composition, discarded milk, higher replacement costs, additional labour, care costs and veterinarian services all add to substantial economic losses for dairy farmers and the milk processing sector. The risk factors that predisposes dairy cows to mastitis may be classified as cow-related, microorganism-related or management-practicesrelated risk factors. Some of the cow-related risk factors are age, lactation, somatic cell count, breed, udder and teat anatomy and the immune status of the animal (Figure 5) [45-52].

\section{MICROORGANISM}

- Type, number, virulence

- Frequency of exposure

- Adhesion and invasion ability

- Zoonotic Potential

- AMR ("Superbugs")

\section{COW-RELATED FACTORS}

- Age

- Breed

- Anatomy of udder and immunity;

- Parity

- Stage of lactation;

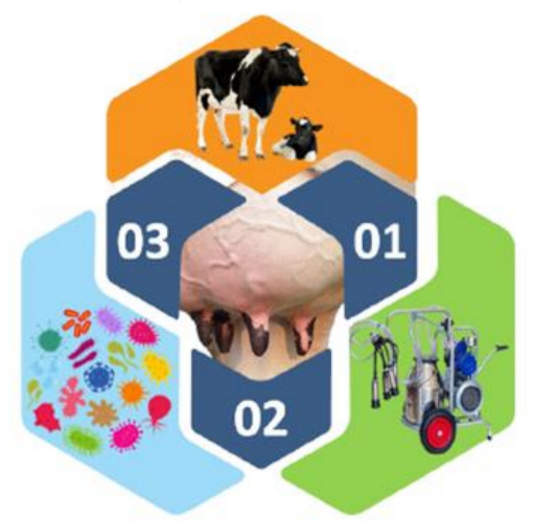

MANAGEMENT PRACTICES

- Climate

- Housing conditions

- Milking hygiene

- Nutrition

- Heat stress

- Antibiotic therapy

Figure 5. Host, microorganism and environmental factors with the potential of inducing mastitis in dairy cows.

The main pathogens that cause mastitis include infectious microorganisms that survive and proliferate on skin and teat wounds, such as Streptococcus agalactiae, Staphylococcus aureus and Streptococcus dysgalactiae, as well as environmental microorganisms such as Streptococcus uberis, Escherichia coli and other coliforms [53,54]. In comparison to contagious pathogens, environmental pathogens typically do not survive on the skin of the cow's udder and teat; they are better characterized as pathogens that are opportunistic, often reside in the bedding and housing, searching for the ability to cause an infection. When the natural immunity of cows is affected, bacteria enter the cow's mammary glands through the teat canal, where they colonize, proliferate, and release toxins, damaging the mammary gland cells. The most common Gram-positive pathogen believed to be involved with different types of clinical and sub-clinical mastitis is Staphylococcus aureus. The main reservoir for Staphylococcus aureus is the cows with chronic infection in the mammary gland; thus, improved udder hygiene will shield healthy cows from infected ones, thereby reducing infection. The intra-mammary administration of antibiotics such as penicillin, ampicillin, tetracycline and gentamycin has always been the first choice for the therapy against bovine mastitis. However, the inappropriate use and overuse of antibiotics in many bacterial species have resulted in an alarming increase in multi-drug-resistant bacterial diseases $[55,56]$. Since some strains are resistant to almost all frequently available agents such as beta-lactams, tetracyclines and amino-glycosidases, there is a major worldwide threat to public health. Since current treatments are becoming progressively more ineffective in resistant bacteria, there is a growing need to increase funding for research and development of new products and technologies to tackle AMR in humans and animals. Thus, the development of innovative products based on both nanotechnology and phytotherapy may directly address a major global problem, antimicrobial resistance, while providing a 
sustainable animal health solution that supports the production of safe and high-quality food products.

\section{New Approaches for the Development of Bovine Mastitis Products-Nanomaterials and Essential Oils}

Not surprisingly, many recent research studies have been aimed at identifying possible alternatives to antibiotic therapy in order to prevent antibiotic resistance [57-72]. A study by Bouari et al. (2016) [73] assessed the in vitro antimicrobial susceptibility of bacteria isolated from mastitic milk to design specific control programs for bovine mastitis in the Transylvanian area (Romania). Among the pathogens identified was Staphylococcus aureus, in which the authors observed increased resistance to penicillin and tetracycline.

Since ancient times, people have widely used natural herbal products as medicines against various diseases. Almost $25 \%$ of the main pharmaceutical compounds and their derivatives available today are produced from natural resources [74], so phytotherapy may be a good starting point for the development of antimicrobial products.

The antimicrobial, immunomodulatory efficacy of medicinal plants has been highlighted in numerous studies over the last few years [75-78], while the potential applications of natural polymers such as chitosan and eco-friendly metal nanoparticles for the development of innovative antimicrobial products have been highlighted in studies by Burdusel et al. (2018) [79], Baican and Vasile (2018) [80], Olaru et al. (2019) [81], Ahmed et al. (2020) [82] and Sánchez-López et al. (2020) [83].

\subsection{Essential Oils and Vegetal Extracts}

Essential oils (EO), which may be derived from various parts of a plant, contain compounds of various types that have both physiological and therapeutic benefits. They can act either individually or in synergy, with antibacterial, antifungal, antiviral and antiinflammatory properties. For example, the biological activities of cinnamon, including its anti-inflammatory characteristics, which are determined by their phenolic and volatile compounds, have been the central subject of several studies conducted in recent years. Studies in vitro and in vivo showed that cinnamon essential oil has bactericidal effects against bovine mastitis pathogenic isolates by impairing the membrane integrity of bacteria, thus constituting an alternative organic antimicrobial to ensure milk safety [84]. Furthermore, cinnamon may reduce both inflammation and the damage of the mammary tissue associated with bovine mastitis disease $[85,86]$.

A study conducted by Nardoni et al. (2018) [87] showed the antialgal efficacy of 30 types of essential oils against Prototheca zopfii and Prototheca blaschkeae, agents that determine protothecal mastitis, an emergent animal health problem in dairy herds. Furthermore, the antimicrobial activity of other essential oils such as thyme, oregano or lavender on common bovine mastitis pathogen such as Staphylococcus sp., Streptococcus sp., Bacillus cereus, Escherichia coli as well as the effect of other plant extract was investigated in different studies [78,88-91] (Table 1).

Table 1. Summary of recent studies regarding the use of essential oils (EO) and plant extracts against mastitis pathogens.

\begin{tabular}{|c|c|c|c|c|}
\hline Type of Oil/Plant Extract & Type of Study & Tested Pathogens & Effect & References \\
\hline $\begin{array}{c}\text { Siam weed EO (Chromolaena squalida) } \\
\text { Guabiroba Verde EO (Campomanesia } \\
\text { sessiliflora) } \\
\text { Rapanea punctata EO (Myrsine } \\
\text { guianensis) } \\
\text { (Matayba guianensis) EO } \\
\text { Negramina EO (Siparuna guianensis) } \\
\text { Canelinha EO (Ocotea minarum) } \\
\text { Endlicheria EO (Endlicheria } \\
\text { paniculata) }\end{array}$ & In vitro & $\begin{array}{c}\text { Staphylococcus aureus } \\
\text { Escherichia coli } \\
\text { Escherichia coli } \\
\text { ( } \beta \text {-lactamase producer) } \\
\text { Pseudomonas aeruginosa }\end{array}$ & $\begin{array}{c}\text { All of the tested oils } \\
\text { demonstrated moderate to } \\
\text { excellent activity against four } \\
\text { bacterial species, including } \\
\text { Salmonella Typhi and } \\
\text { oxacillin-resistant Staphylococcus } \\
\text { aureus. }\end{array}$ & $\begin{array}{c}\text { de Jesus et al. } \\
2020 \text { [92] }\end{array}$ \\
\hline
\end{tabular}


Table 1. Cont.

\begin{tabular}{|c|c|c|c|c|}
\hline Type of Oil/Plant Extract & Type of Study & Tested Pathogens & Effect & References \\
\hline $\begin{array}{l}\text { FMexican Avocado Seed } \\
\text { (Persea americana var. drymifolia) }\end{array}$ & In vitro & Staphylococcus aureus & $\begin{array}{l}\text { Lipid extract from avocado seed } \\
\text { inhibits the Staphylococcus aureus } \\
\text { internalization into bovine } \\
\text { mammary epithelial cells } \\
\text { (bMECs) and modulates the } \\
\text { innate immune response (IIR) }\end{array}$ & $\begin{array}{c}\text { Báez-Magaña et al. } \\
2019 \text { [93] }\end{array}$ \\
\hline $\begin{array}{c}\text { Pink Powderpuff (Calliandra } \\
\text { surinamensis) }\end{array}$ & In vitro & $\begin{array}{l}\text { Staphylococcus isolates } \\
\text { from either bovine } \\
\text { (Ssp6PD and Sa) or } \\
\text { caprine (Ssp5D and } \\
\text { Ssp01) mastitic milk } \\
\text { samples }\end{array}$ & $\begin{array}{c}\text { Calliandra surinamensis leaf } \\
\text { pinnulae lectin displayed a } \\
\text { bacteriostatic and antibiofilm } \\
\text { agent against certain bovine and } \\
\text { caprine mastitis isolates. When } \\
\text { used in conjunction with either } \\
\text { ampicillin (against one isolate) } \\
\text { or tetracycline (against two } \\
\text { isolates), it showed synergistic } \\
\text { effect. }\end{array}$ & $\begin{array}{l}\text { Procópio et al. } \\
2019 \text { [94] }\end{array}$ \\
\hline $\begin{array}{c}\text { Southern blue gum (Eucalyptus } \\
\text { globulus) } \\
\text { Walnut (Juglans regia) }\end{array}$ & In vitro & Staphylococcus aureus & $\begin{array}{l}\text { Eucalyptus globulus extract alone } \\
\text { appeared to have a bacteriostatic } \\
\text { effect against Staphylococcus } \\
\text { aureus, up to } 8 \text { hours of } \\
\text { incubation. When opposed to } \\
\text { the positive control, Eucalyptus } \\
\text { globulus and Juglans regia extracts } \\
\text { alone had a minor inhibitory } \\
\text { effect over time. }\end{array}$ & $\begin{array}{c}\text { Gomes et al. } 2019 \\
\text { [95] }\end{array}$ \\
\hline $\begin{array}{c}\text { Black Myrobalan (Terminalia chebula) } \\
\text { extract }\end{array}$ & In Vitro & Staphylococcus aureus & $\begin{array}{l}\text { The } 500 \mu \mathrm{g} / \mathrm{mL} \text { concentration of } \\
\text { Terminalia chebula ethyl acetate } \\
\text { extract was as effective as } \\
\text { standard amoxicillin }\end{array}$ & $\begin{array}{l}\text { Kher et al. } 2019 \\
\text { [96] }\end{array}$ \\
\hline $\begin{array}{l}\text { Rose Myrtle Rhodomyrtus } \\
\text { tomentosa (Rose myrtle) leaves }\end{array}$ & In vitro In vivo & Staphylococcus aureus & $\begin{array}{l}\text { The ethanolic extract showed } \\
\text { good antibacterial activity } \\
\text { in vitro, a reduction of activity } \\
\text { being observed in vivo. }\end{array}$ & $\begin{array}{l}\text { Mordmuang et al. } \\
2019 \text { [97] }\end{array}$ \\
\hline Wild cabbage (Brassica oleracea) & In vitro & $\begin{array}{c}\text { Staphylococcus aureus } \\
\text { Escherichia coli Klebsiella } \\
\text { pneumoniae }\end{array}$ & $\begin{array}{l}\text { Interferes in the mechanisms of } \\
\text { action of genes such as MTOR } \\
\text { and TP53, thus may be a possible } \\
\text { alternative for developing herbal } \\
\text { formulations for bovine mastitis. }\end{array}$ & $\begin{array}{l}\text { Sobrinho Santos } \\
\text { et al. } 2019 \text { [98] }\end{array}$ \\
\hline $\begin{array}{c}\text { Piperina EO (Minthostachys } \\
\text { verticillata) }\end{array}$ & In vitro & $\begin{array}{l}\text { Escherichia coli Bacillus } \\
\text { pumilus Enterococcus } \\
\text { faecium }\end{array}$ & $\begin{array}{l}\text { EO affected the formation of } \\
\text { biofilm and revealed the } \\
\text { antibacterial capacity of EO and } \\
\text { limonene. }\end{array}$ & $\begin{array}{c}\text { Cerioli et al. } 2018 \\
\text { [90] }\end{array}$ \\
\hline $\begin{array}{c}\text { Oregano EO (Origanum floribundu) } \\
\text { Morrocan Thyme EO (Thymus } \\
\text { ciliatus) }\end{array}$ & In vitro & Candida albicans & $\begin{array}{l}\text { The three essential oils showed } \\
\text { highly anticandidal activity, with } \\
\text { values ranging from } 15.02 \text { to }\end{array}$ & $\begin{array}{c}\text { Ksouri et al. } 2017 \\
\text { [99] }\end{array}$ \\
\hline $\begin{array}{c}\text { Rosemary EO (Rosmarinus officinalis) } \\
\text { Cinnamon EO } \\
\text { (Cinnamomum zeylandicum) } \\
\text { Geranium EO (Pelargonium }\end{array}$ & & & $31.08 \mathrm{~g} / \mathrm{mL}$ & \\
\hline $\begin{array}{c}\text { graveolens) } \\
\text { Clove EO (Syzygium aromaticum) } \\
\text { Thyme EO (Thymus vulgaris) } \\
\text { Lavender EO (Lavandula angustifolia) } \\
\text { Basil EO (Ocimum basilicum) } \\
\text { Rosemary EO (Rosmarinus officinalis) } \\
\text { Clary sage EO (Salvia sclarea) }\end{array}$ & In vitro & $\begin{array}{l}\text { Eight strains of } \\
\text { Prototheca zopfii isolated } \\
\text { from mastitic milk }\end{array}$ & $\begin{array}{l}\text { Many of the oils tested were } \\
\text { effective against algal strains, } \\
\text { but cinnamon, clove, and thyme } \\
\text { were the most effective. }\end{array}$ & $\begin{array}{l}\text { Grzesiak et al. } \\
\text { 2016 [91] }\end{array}$ \\
\hline Oregano EO (Origanum vulgare) & In vivo & $\begin{array}{l}\text { Staphylococcus aureus } \\
\text { and Escherichia coli }\end{array}$ & $\begin{array}{l}\text { In the group of cows treated } \\
\text { intramammary with oregano } \\
\text { essential oil (OEO), the number } \\
\text { of somatic cells (SCCs) and } \\
\text { number of white blood cells } \\
\text { (WBC) were significantly } \\
\text { decreased and Staphylococcus } \\
\text { aureus and Escherichia coli were } \\
\text { not present in milk samples. }\end{array}$ & $\begin{array}{l}\text { Cho et al. } 2015 \\
\text { [100] }\end{array}$ \\
\hline
\end{tabular}


Table 1. Cont.

\begin{tabular}{|c|c|c|c|c|}
\hline Type of Oil/Plant Extract & Type of Study & Tested Pathogens & Effect & References \\
\hline $\begin{array}{c}\text { Thyme EO (Thymus vulgaris); } \\
\text { Lavender EO (Lavandula angustifolia) }\end{array}$ & $\begin{array}{c}\text { In vitro } \\
\text { In vivo } \\
\text { Intramammary } \\
\text { and External } \\
\text { applications (oils } \\
\text { mixed in vaseline) }\end{array}$ & $\begin{array}{l}\text { Staphylococcus sp. And } \\
\text { Streptococcus sp. }\end{array}$ & $\begin{array}{l}\text { External use of these oils in } \\
\text { vaseline resulted in a greater } \\
\text { antibacterial action, for a } 100 \% \\
\text { recovery rate with thymus } \\
\text { essential oils. }\end{array}$ & $\begin{array}{l}\text { Abboud et al. } \\
\text { 2015 } \\
\text { [51] }\end{array}$ \\
\hline $\begin{array}{c}\text { Cinnamon EO (Cinnamomum } \\
\text { zeylanicum) }\end{array}$ & & & $\begin{array}{l}\text { The mixture containing Thymus } \\
\text { vulgaris and Winter savory }\end{array}$ & \\
\hline Bergamot EO (Citrus bergamia Risso) & & Staphylococcus aureus & essential oils exhibited the best & \\
\hline $\begin{array}{l}\text { Tasmanian blue gum EO (Eucalyptus } \\
\text { globulus) }\end{array}$ & & $\begin{array}{l}\text { Staphylococcus } \\
\text { chromogenes }\end{array}$ & $\begin{array}{l}\text { inhibitory activity against all the } \\
\text { tested bacterial strains. The }\end{array}$ & \\
\hline $\begin{array}{c}\text { Fennel EO (Foeniculum vulgare) } \\
\text { Marjoram EO (Origanum majorana) }\end{array}$ & In vitro & $\begin{array}{l}\text { Staphylococcus sciuri } \\
\text { Staphylococcus warneri }\end{array}$ & $\begin{array}{l}\text { artificial mixtures composed of } \\
\text { carvacrol/thymol, respectively }\end{array}$ & $\begin{array}{c}\text { Fratini et al. } 2014 \\
\text { [101] }\end{array}$ \\
\hline Oregano EO (Origanum vulgare) & & Staphylococcus xylosus & carvacrol/thymol/p-cymene & \\
\hline Rosemary EO (Rosmarinus officinalis) & & Escherichia coli & presented strong inhibition & \\
\hline Winter savory EO (Satureja montana) & & & against Staphylococcus aureus and & \\
\hline Thyme EO (Thymus vulgaris) & & & Staphylococcus sciuri & \\
\hline $\begin{array}{c}\text { Summer savory (Satureja hortensis) } \\
\text { Silver fir (Abies alba) }\end{array}$ & In vitro & $\begin{array}{c}\text { Prototheca zopfii isolates } \\
\text { (from mastitic milk and } \\
\text { bovine feces) Prototheca } \\
\text { wickerhami }\end{array}$ & $\begin{array}{l}\text { Fir oil is presented lower } \\
\text { anti-algae activity as compared } \\
\text { to summer savory }\end{array}$ & $\begin{array}{c}\text { Bouari et al. } 2011 \\
\text { [102] }\end{array}$ \\
\hline
\end{tabular}

Worldwide products based on herbal extracts and essential oils under the form of a spray or ointment have been used for the treatment of mastitis in ruminants, especially in organic farms [103]. However, despite their great potential as non-antibiotic antibacterial agents, essential oils have several disadvantages, including instability, intense smell, biodegradability and low solubility in certain solutions. These issues have limited the applications of essential oils in the food and medical industries. Moreover, newer research has shown that the effectiveness of phytotherapy could be greatly improved, including against antibiotic-resistant pathogens, by its association with metal nanoparticles, enabling the development of systems for the distribution and controlled release of essential oils [104,105].

\subsection{Metallic Nanoparticles}

Metallic nanoparticles are submicron-size entities with a metal core composed of inorganic metal or metal oxide, and they are usually covered by a shell layer of organic or inorganic material or metal oxide. The use of nanoparticles in numerous fields such as energy [106,107], biomedicine [108-112], assisted reproduction [113-115], wood industry [116-118], food industry [119-121] and agriculture [122-127] has risen exponentially in recent years.

Metallic nanoparticles may be synthesized by various methods, through top-down (e.g., laser ablation, ball milling and chemical etching) and bottom-up approaches (e.g., chemical vapor deposition, sol-gel process, spray pyrolysis and green synthesis). The top-down strategy implies that the bulk material is converted into small, nano-sized structures, using different reagents and physical treatments. In the bottom-up approach, nanoparticles are grown to a specific size and shape from simpler molecules [128-132].

In contrast with the nanoparticles derived from physical and chemical synthesis, which pose a high health and toxicity risk, the green synthesized nanoparticles are safer, eco-friendly alternatives because the obtaining process is clean and non-toxic [133-135]. Green synthesized metallic nanoparticles may be obtained using leaves [136-138], flowers $[139,140]$, seeds [141,142], peel [143,144] or roots [145,146] (Figure 6). Moreover, the production of different types of metallic nanoparticles using agro-waste has become more and more popular [147-150]. 


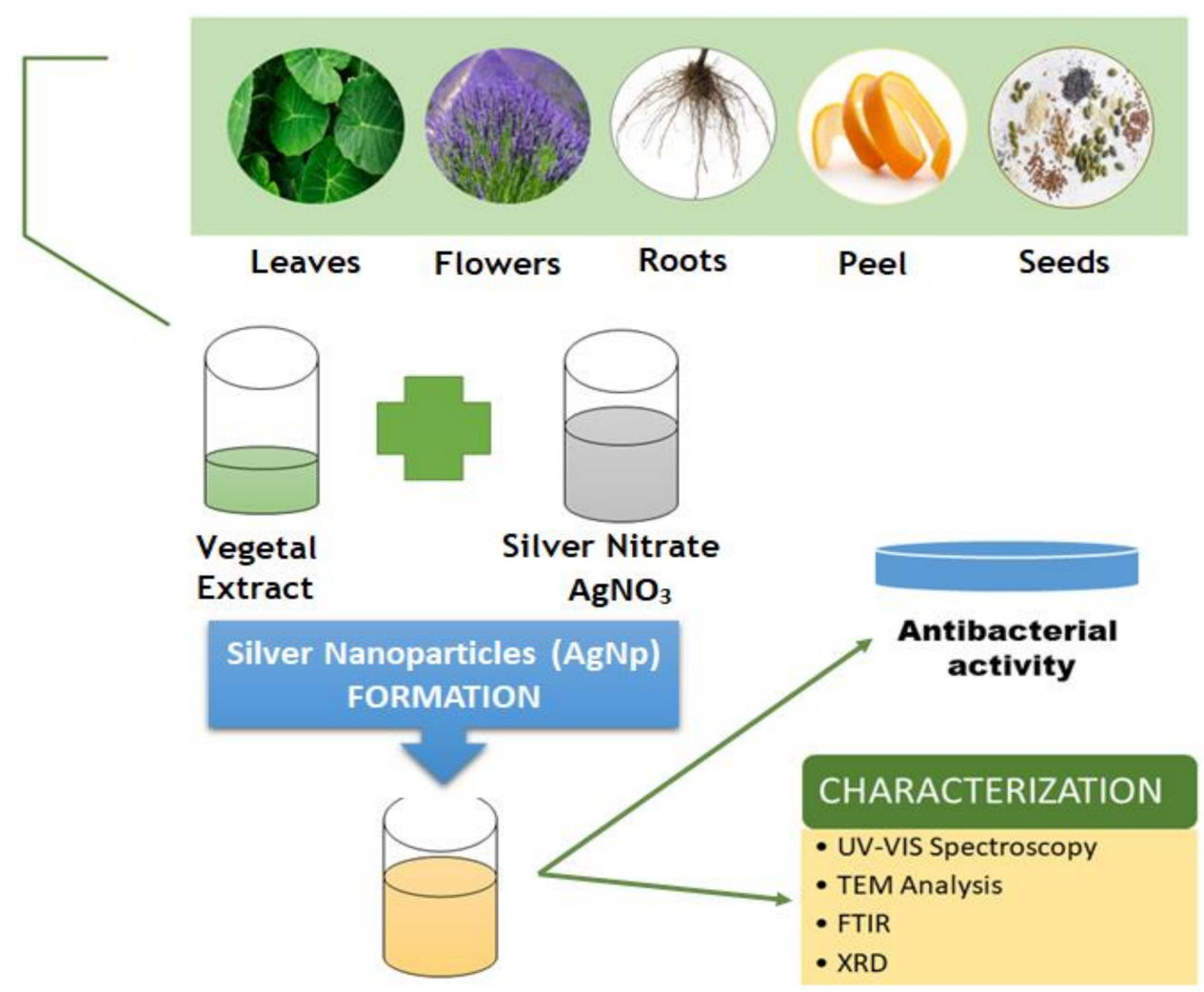

Figure 6. Schematic representation of silver nanoparticles green synthesis.

The antimicrobial effects of metallic nanoparticles (NPs) are mainly due to the release of metallic ions, disruption of the cell membrane/wall, generation of ROS and inhibition of proper DNA replication [151-154]. The reaction parameters such as $\mathrm{pH}$, temperature and reaction time may be adapted in order to produce metallic nanoparticles with desired shape and size $[155,156]$.

These physical characteristics may be further exploited for the development of antimicrobial products. Besides their antibacterial activity, metallic nanoparticles may be effective against bovine mastitis pathogens (Table 2) and methicillin-resistant bacteria, inhibiting biofilms [157-159].

Table 2. Summary of recent studies regarding the use of nanoparticles against bovine mastitis pathogens.

\begin{tabular}{|c|c|c|c|c|}
\hline Type of Nanoparticles & Type of Study & Tested Pathogens & Effect & References \\
\hline $\begin{array}{l}\text { Silver nanoparticles } \\
\text { (AgNPs) }\end{array}$ & in vitro & Streptococcus agalactiae & $\begin{array}{l}\text { AgNPs showed reasonable } \\
\text { antimicrobial and relatively low } \\
\text { antibiofilm activities, while cinnamon } \\
\text { oil showed high antimicrobial and } \\
\text { antibiofilm against biofilms of } \\
\text { Streptococcus agalactiae isolates. }\end{array}$ & $\begin{array}{l}\text { Abd El-Aziz et al. } \\
2021 \text { [160] }\end{array}$ \\
\hline $\begin{array}{l}\text { Chitosan nanoparticles } \\
\text { (Ch-NPs) }\end{array}$ & in vitro & Staphylococcus aureus & $\begin{array}{l}\text { The smaller Ch-NPs were active in } \\
\text { preventing Staphylococcus aureus from } \\
\text { entering the cells, but they did not } \\
\text { stimulate the formation of } \\
\text { pro-inflammatory cytokines. The } \\
\text { results support the assertion that } \\
\text { Ch-NPs are an excellent bacteriostatic } \\
\text { agent, capable of preventing the } \\
\text { replication of bovine mastitis } \\
\text { pathogens in the udder. }\end{array}$ & $\begin{array}{c}\text { Orellano et al. } 2021 \\
\text { [161] }\end{array}$ \\
\hline
\end{tabular}


Table 2. Cont.

\begin{tabular}{|c|c|c|c|c|}
\hline Type of Nanoparticles & Type of Study & Tested Pathogens & Effect & References \\
\hline $\begin{array}{l}\text { Chitosan nanoparticles } \\
\text { (Ch-NPs) }\end{array}$ & in vitro & $\begin{array}{c}\text { Pseudomonas sp. strain } \\
\text { isolated from bovine milk } \\
\text { samples }\end{array}$ & $\begin{array}{l}\text { The nanoparticles inhibited biofilm } \\
\text { formation and could eliminate } \\
\text { pre-existing mature biofilms. }\end{array}$ & $\begin{array}{c}\text { Rivera Aguayo et al. } \\
2020[162]\end{array}$ \\
\hline $\begin{array}{l}\text { Chitosan nanoparticles } \\
\text { (Ch-NPs) }\end{array}$ & in vitro & Staphylococcus aureus & $\begin{array}{l}\text { The antimicrobial activity of Ch-NP } \\
\text { was higher than that of the native } \\
\text { polymer used in the nanocomposites' } \\
\text { preparation. Ch-NPs impaired } \\
\text { bacterial cell membranes and } \\
\text { prevented the development of bacterial } \\
\text { biofilms without impacting the } \\
\text { viability of bovine cells. }\end{array}$ & $\begin{array}{c}\text { Orellano et al, } 2019 \\
\text { [163] }\end{array}$ \\
\hline $\begin{array}{l}\text { inc oxide nanoparticles } \\
\text { (ZnO-NPs) }\end{array}$ & in vitro & $\begin{array}{l}\text { Staphylococcus aureus } \\
\text { Escherichia coli Klebsiella } \\
\text { pneumoniae isolated from } \\
\text { milk of affected cows. }\end{array}$ & $\begin{array}{l}\text { At the same concentrations, capped } \\
\text { dispersed ZnO-NPs demonstrated } \\
\text { greater antibacterial activity against } \\
\text { Staphylococcus aureus, Escherichia coli } \\
\text { Klebsiella pneumoniae than non-capped } \\
\text { nanoparticles. Gram-positive } \\
\text { Staphylococcus aureus showed higher } \\
\text { resistance to ZnO-NPs synthesized as } \\
\text { compared to Gram-negative Escherichia } \\
\text { coli Klebsiella pneumoniae. }\end{array}$ & $\begin{array}{c}\text { Hozyen et al. } 2019 \\
\text { [164] }\end{array}$ \\
\hline $\begin{array}{l}\text { Silver-nanoparticle- } \\
\text { decorated quercetin } \\
\text { nanoparticles } \\
\text { (QA NPs) }\end{array}$ & in vitro & $\begin{array}{l}\text { Escherichia coli multi-drug } \\
\text { resistant strain isolated } \\
\text { from a dairy cow with } \\
\text { mastitis }\end{array}$ & $\begin{array}{l}\text { QA NPs showed higher antibacterial } \\
\text { and anti-biofilm properties in a } \\
\text { multi-drug resistant Escherichia coli } \\
\text { strain isolated from a dairy cow with } \\
\text { mastitis, as compared to Ag NPs and } \\
\text { quercetin alone. }\end{array}$ & Yu et al. 2018 [165] \\
\hline $\begin{array}{l}\text { Honey and Gold } \\
\text { Nanoparticles }\end{array}$ & in vitro & $\begin{array}{l}\text { Methicillin-resistant } \\
\text { (MRSA) and } \\
\text { vancomycin-resistant } \\
\text { (VRSA) coagulase-positive } \\
\text { Staphylococcus aureus } \\
\text { isolated from contagious } \\
\text { bovine clinical mastitis }\end{array}$ & $\begin{array}{c}\text { AuNPs, } 30 \mathrm{~nm} \text { in size, presented } \\
\text { visible anti- Methicillin-resistant } \\
(M R S A) \text { and anti-vancomycin-resistant } \\
(V R S A) \text { activities in vitro }\end{array}$ & $\begin{array}{c}\text { Omara et al. } 2017 \\
{[166]}\end{array}$ \\
\hline
\end{tabular}

Moreover, in the treatment of bovine mastitis, nanoparticles show greater effects on bacteria than their micro-counterparts and may serve as potential delivery systems because they may be ingested by phagocytes [11,167]. According to Pinheiro Machado et al. (2019) [168], nanoparticles may be used as a carrier for the efficient delivery of nanopropolis formulation [169-172]. Due to its improved antimicrobial activity as well as low cytotoxicity, this type of therapeutical alternative for bovine mastitis control is gaining popularity in organic dairy farms. Furthermore, studies conducted by Soni and Yadav (2016) [173], Krishna et al. (2017) [174], Mohsenabadi et al. (2018) [175] and Vasile et al. (2020) [176], have shown that nanogels may be an outstanding method to address the therapeutic challenges posed by intracellular pathogens such as Staphylococcus aureus.

More recently, the potential of new-generation antibacterial materials such as graphenebased nanomaterials were also exploited $[177,178]$. Graphene oxide (GO) and reduced graphene oxide (rGO) showed excellent potential in drug delivery and photodynamic/ photothermal therapy, as well as antimicrobial properties due to their composition and physicochemical characteristics [178-180]. According to some studies, these materials may be used in synergism with other biocidal material, such as rare metal nanoparticles [181,182] or essential oils [183] with applications in various sectors such as biomedicine and food safety. By enriching their antibacterial properties, these materials may be a promising tool even against multidrug-resistant agents such as Methicillin-resistant Staphylococcus aureus (MRSA) [184-187].

According to recent studies, graphene-based materials are being used successfully in tissue engineering and regenerative medicine due to their potential to improve both the wound-healing process and infection control at the injury site [188-191]. Since the lesions on 
teat skin commonly harbor bacteria that may cause mastitis, consequently leading to partial or complete damage to udder tissues and reduced milk production, the anti-inflammatory and regenerative properties of graphene may be exploited in the development of innovative formulations. According to Pelin et al. (2017) [192], the cytotoxicity of graphene oxide at skin level is low, which is why graphene-based products may be safely used for the development of a nanogel with topical applications on the udder skin for the treatment and prevention of bovine mastitis.

\section{Challenges}

The administration of oral pharmacological substances is, so far, the most convenient and accepted way of administering drugs, but in recent years, the science of drug delivery has reached unprecedented landmarks, thus, presently there is considerable interest in the administration of drugs to the systemic circulation, in a non-invasive manner, through mucosal routes (ophthalmic, rectal, vaginal) or skin [193]. The development of innovative drug delivery methods and the nanotechnological advancements have catapulted topical drug delivery to a whole new era [194,195]. However, delivering the active substances into the bloodstream topically, using a non-invasive manner, remains a challenge.

An effective topical formulation must meet two concomitant characteristics, namely being thermodynamically stable while allowing the transport of the active substance through the stratum corneum of the skin, thus guaranteeing that the necessary therapeutic amount of drug reaches the targeted region [196-200]. A poor percutaneous penetration capability for most topical antibacterial and anti-inflammatory formulations is one of the main causes compromising their therapeutic effects [201]. The transdermal delivery of active compounds is a challenge that may be solved by hydrogels [202-204]. These promising 3D materials have demonstrated increasing applications in the encapsulation and topical delivery of drugs due to specific properties such as high hydrophilicity, unique threedimensional network, fine biocompatibility and cell adhesion [204,205]. These distinctive properties give hydrogels the ability to protect the pharmacological substance against biodegradation while also ensuring its controlled and regulated release. Furthermore, hydrogels may be functionalized using different nanomaterials such as nanotubes, graphene, dendrimers, ceramic and metallic nanoparticles. The integration of nanomaterials within a polymeric hydrogel network is an appealing method for personalizing the mechanical properties of the hydrogels and/or improving the responsiveness to external stimuli [206].

Nanoparticles may act as a multifunctional cross-linking point in three-dimensional polymeric chains; thus, the size and shape of the nanoparticles may influence the mechanical strength of the nanocomposite hydrogel [207,208]. Metallic nanoparticles are well known for their antimicrobial activity against a broad range of bacteria strains, including an antibiotic-resistant strain, making them suitable for the formulation of nanogels with antimicrobial activity [201,207,209-212].

Graphene-based nanomaterials also show impressive antimicrobial characteristics [213,214]. However, due to their powerful inter-plane interactions, they tend to aggregate, which is why their surface area and mode of action is presently limited. Therefore, different functionalization and surface modification with metal ions/oxides/sulfides NPs, polymers and enzymes must be conducted on graphene in order to decrease aggregation and improve biosafety.

Many attempts have been made over the last several years to produce selective drug delivery systems that allow medication to be delivered to particular locations such as muscles, tissues and cells in the body to enhance treatment management. Nanogels are among the most promising drug delivery systems due to their unique structure that combines the properties and features of both hydrogels and nanoparticles.

\section{Conclusions}

Routine animal health assessments, as a core technique for infection prevention and control on farms, as well as the dissemination of best practices at the regional and national 
levels, may enhance animal health and food safety. This strategy might help limit food contamination and antibiotic consumption on farms. In the same way as reducing human infection reduces antimicrobial use (and so the risk of AMR), reducing animal infection reduces antimicrobial use and hence the risk of AMR.

However, more resistance might naturally arise as a result of evolution. Therefore, any strategy to counteract AMR must have an emphasis on enhancing the manufacturing and use of highly effective new antimicrobials, vaccines and infection prevention therapies.

Nanomaterials have great potential in the development of new drug formulas, as an alternative to current therapy products, the benefits of these new types of formulas being determined both by the diversity of excipients and by their particularly advantageous specific properties such as relative abundance, biocompatibility, biodegradability, nonirritability, innocuity and low-cost price.

In addition, essential oils are recognized as biocompatible, biodegradable and nontoxic, and due to their ability to penetrate the skin barrier, these compounds may be used alongside other nanomaterials to improve both the transdermal transport of the newly developed products, as well as their efficiency.

Author Contributions: Conceptualization, A.S.N.-V. and A.M.A.; writing—original draft preparation, A.S.N.-V. and B.M.M.; writing-review and editing A.M.A.; visualization, C.M.R.; Supervision, S.C.; project administration, A.S.N.-V. All authors have read and agreed to the published version of the manuscript.

Funding: This research received funding through the ASAS Heritage Foundation, grant number 73/25.09.2020.

Conflicts of Interest: The authors declare no conflict of interest.

\section{References}

1. Overview Report of the Directorate-General for Health and Food Safety on a Series of Audits Carried Out in 2016 in Order to Evaluate Member State Controls and Use of Indicators to Ensure the Welfare of Cattle on Dairy Farms. 2017. Available online: https:/ / ec.europa.eu/food/audits-analysis/overview_reports (accessed on 1 March 2021).

2. Reshi, A.A.; Husain, I.; Bhat, S.A.; Rehman, M.U.; Razak, R.; Bilal, S.; Mir, M.R. Bovine Mastitis as an Evolving Disease and Its Impact on the Dairy Industry. Int. J. Curr. Res. Rev. 2015, 7, 48-55.

3. Li, N.; Richoux, R.; Boutinaud, M.; Martin, P.; Gagnaire, V. Role of somatic cells on dairy processes and products: A review. Dairy Sci. Technol. 2014, 94, 517-538. [CrossRef] [PubMed]

4. Alhussien, M.N.; Dang, A.K. Impact of different seasons on the milk somatic and differential cell counts, milk cortisol and neutrophils functionality of three Indian native breeds of cattle. J. Therm. Biol. 2018, 78, 27-35. [CrossRef]

5. Cobirka, M.; Tancin, V.; Slama, P. Epidemiology and Classification of Mastitis. Animals 2020, 10, 2212. [CrossRef] [PubMed]

6. Dufour, S.; Labrie, J.; Jacques, M. The Mastitis Pathogens Culture Collection. Microbiol. Resour. Announc. 2019, 8, e00133-19. [CrossRef] [PubMed]

7. Tarazona-Manrique, L.E.; Villate-Hernández, J.R.; Andrade-Becerra, R.J. Bacterial and fungal infectious etiology causing mastitis in dairy cows in the highlands of Boyacá (Colombia). Rev. Fac. Med. Vet. Zootec. 2019, 66, 208-218. [CrossRef]

8. Ashraf, A.; Imran, M. Causes, types, etiological agents, prevalence, diagnosis, treatment, prevention, effects on human health and future aspects of bovine mastitis. Anim. Health Res. Rev. 2020, 21, 36-49. [CrossRef] [PubMed]

9. Bórawski, P.; Pawlewicz, A.; Parzonko, A.; Jayson, K.H.; Holden, L. Factors Shaping Cow's Milk Production in the EU. Sustainability 2020, 12, 420. [CrossRef]

10. Fortune Business Insights. Market Research Report "Bovine Mastitis Market Size, Share \&COVID-19 Impact Analysis, By Type (Clinical, and Sub-Clinical), By Product (Antibiotics, and Others), By Route of Administration (Intra-Mammary, and Systemic), By Therapy (Lactating Period and Dry Period) and Regional Forecast, 2020-2027. August 2020. Available online: https:/ / www.fortunebusinessinsights.com/bovine-mastitis-market-103482 (accessed on 1 March 2021).

11. Hill, E.K.; Li, J. Current and future prospects for nanotechnology in animal production. J. Anim. Sci. Biotechnol. 2017, 8, 26. [CrossRef]

12. Youssef, F.S.; El-Banna, H.A.; Elzorba, H.Y.; Galal, A.M. Application of some nanoparticles in the field of veterinary medicine. Int. J. Vet. Sci. Med. 2019, 7, 78-93. [CrossRef]

13. El-Sayed, A.; Kamel, M. Advanced applications of nanotechnology in veterinary medicine. Environ. Sci. Pollut. Res. 2020, 27, 19073-19086. [CrossRef]

14. Cerbu, C.; Kah, M.; White, J.; Astete, C.; Sabliov, C. Fate of Biodegradable Engineered Nanoparticles Used in Veterinary Medicine as Delivery Systems from a One Health Perspective. Molecules 2021, 26, 523. [CrossRef] 
15. Huang, S.; Wang, L.; Liu, L.; Hou, Y.; Li, L. Nanotechnology in agriculture, livestock, and aquaculture in China. A review. Agron. Sustain. Dev. 2015, 35, 369-400. [CrossRef]

16. Gopi, M.; Pearlin, B.; Kumar, R.D.; Shanmathy, M.; Prabakar, G. Role of Nanoparticles in Animal and Poultry Nutrition: Modes of Action and Applications in Formulating Feed Additives and Food Processing. Int. J. Pharmacol. 2017, 13, 724-731. [CrossRef]

17. Konkol, D.; Wojnarowski, K. The Use of Nanominerals in Animal Nutrition as a Way to Improve the Composition and Quality of Animal Products. J. Chem. 2018, 2018, 5927058. [CrossRef]

18. Fesseha, H.; Degu, T.; Getachew, Y. Nanotechnology and its Application in Animal Production: A Review. Vet. Med. Open J. 2020, 5, 43-50. [CrossRef]

19. ESVAC (European Medicines Agency). European Database of Sales of Veterinary Antimicrobial Agents. Available online: https: / / esvacbi.ema.europa.eu/analytics/saw.dll?PortalPages (accessed on 10 May 2021).

20. ESVAC: Vision, Strategy and Objectives 2016-2020 Surveillance of Veterinary Antimicrobial Consumption. Available online: https://www.ema.europa.eu/en/documents/regulatory-procedural-guideline/european-surveillance-veterinaryantimicrobial-consumption-esvac-vision-strategy-2016-2020_en.pd (accessed on 10 May 2021).

21. ECDC; EFSA; EMA. ECDC, EFSA and EMA Joint Scientific Opinion on a list of outcome indicators as regards surveillance of antimicrobial resistance and antimicrobial consumption in humans and food-producing animals. EFSA J. 2017, 15 , e05017. [CrossRef]

22. Sales of Veterinary Antimicrobial Agents in 31 European Countries in 2018. Trends from 2010 to 2018-Tenth ESVAC Report. Available online: https://www.ema.europa.eu/en/documents/report/sales-veterinary-antimicrobial-agents-31-europeancountries-2018-trends-2010-2018-tenth-esvac-report_en.pdf (accessed on 10 May 2021).

23. Kimera, Z.I.; Mshana, S.E.; Rweyemamu, M.M.; Mboera, L.E.G.; Matee, M.I.N. Antimicrobial use and resistance in food-producing animals and the environment: An African perspective. Antimicrob. Resist. Infect. Control. 2020, 9, 37. [CrossRef]

24. Aiassa, V.; Barnes, A.I.; Smania, A.M.; Albesa, I. Sublethal ciprofloxacin treatment leads to resistance via antioxidant systems in Proteus mirabilis. FEMS Microbiol. Lett. 2012, 327, 25-32. [CrossRef]

25. Jørgensen, K.M.; Wassermann, T.; Jensen, P.Ø.; Hengzuang, W.; Molin, S.; Høiby, N.; Ciofu, O. Sublethal Ciprofloxacin Treatment Leads to Rapid Development of High-Level Ciprofloxacin Resistance during Long-Term Experimental Evolution of Pseudomonas aeruginosa. Antimicrob. Agents Chemother. 2013, 57, 4215-4221. [CrossRef] [PubMed]

26. Andersson, D.I.; Hughes, D. Microbiological effects of sublethal levels of antibiotics. Nat. Rev. Microbiol. 2014, 12, 465-478. [CrossRef] [PubMed]

27. Knudsen, G.M.; Fromberg, A.; Ng, Y.; Gram, L. Sublethal Concentrations of Antibiotics Cause Shift to Anaerobic Metabolism in Listeria monocytogenes and Induce Phenotypes Linked to Antibiotic Tolerance. Front. Microbiol. 2016, 7, 1091. [CrossRef]

28. Li, J.; Phulpoto, I.A.; Zhang, G.; Yu, Z. Acceleration of emergence of E. coli antibiotic resistance in a simulated sublethal concentration of copper and tetracycline co-contaminated environment. AMB Express 2021, 11, 14. [CrossRef]

29. Manyi-Loh, C.; Mamphweli, S.; Meyer, E.; Okoh, A. Antibiotic Use in Agriculture and Its Consequential Resistance in Environmental Sources: Potential Public Health Implications. Molecules 2018, 23, 795. [CrossRef] [PubMed]

30. Jones, I.; Joshi, L. Biocide Use in the Antimicrobial Era: A Review. Molecules 2021, 26, 2276. [CrossRef] [PubMed]

31. Antimicrobial-Consumption-in-the-EU-Annual-Epidemiological-Report. Available online: https://www.ecdc.europa.eu/sites/ default / files/documents / Antimicrobial-consumption-in-the-EU-Annual-Epidemiological-Report-2019.pdf (accessed on 10 May 2021).

32. In the Red Zone Antimicrobial Resistance: Lessons from Romania. Available online: https://epha.org/wp-content/uploads/20 17/06/In-the-red-zone-EPHA.pdf (accessed on 10 May 2021).

33. Torumkuney, D.; Nica, M.; Nistor, I.; Vatcheva-Dobrevska, R.; Petrović, V.; Stoica, A.; Hanicar, B.; Antic, D.; Morrissey, I. Results from the Survey of Antibiotic Resistance (SOAR) 2014-16 in Bulgaria, Romania, Serbia and Croatia. J. Antimicrob. Chemother. 2018, 73, v2-v13. [CrossRef] [PubMed]

34. Tiseo, K.; Huber, L.; Gilbert, M.; Robinson, T.P.; Van Boeckel, T.P. Global Trends in Antimicrobial Use in Food Animals from 2017 to 2030. Antibiotics 2020, 9, 918. [CrossRef]

35. Nolte, O. Antimicrobial resistance in the 21st century: A multifaceted challenge. Protein Pept. Lett. 2014, 21, 330-335. [CrossRef]

36. Barriere, S.L. Clinical, economic and societal impact of antibiotic resistance. Expert Opin. Pharmacother. 2015, 16, 151-153. [CrossRef]

37. Friedman, N.; Temkin, E.; Carmeli, Y. The negative impact of antibiotic resistance. Clin. Microbiol. Infect. 2016, 22, 416-422. [CrossRef]

38. Naylor, N.R.; Atun, R.; Zhu, N.; Kulasabanathan, K.; Silva, S.; Chatterjee, A.; Knight, G.M.; Robotham, J.V. Estimating the burden of antimicrobial resistance: A systematic literature review. Antimicrob. Resist. Infect. Control. 2018, 7, 58. [CrossRef]

39. Nathan, C. Resisting antimicrobial resistance. Nat. Rev. Genet. 2020, 18, 259-260. [CrossRef]

40. Addressing Antimicrobial Resistance: Progress in the Animal Sector, But This Health Threat Remains a Challenge for the EU. Special Report by European Court of Auditors. 2019. Available online: https://www.stopamr.eu/wp-content/uploads/2019/11/ ECA-AMR-report.pdf (accessed on 8 March 2021).

41. Amann, S.; Neef, K.; Kohl, S. Antimicrobial resistance (AMR). Eur. J. Hosp. Pharm. 2019, 26, 175-177. [CrossRef]

42. Davies, R.; Wales, A. Antimicrobial Resistance on Farms: A Review Including Biosecurity and the Potential Role of Disinfectants in Resistance Selection. Compr. Rev. Food Sci. Food Saf. 2019, 18, 753-774. [CrossRef] [PubMed] 
43. Blake, O.; Glaser, M.; Bertolini, L.; te Brömmelstroet, M. How policies become best practices: A case study of best practice making in an EU knowledge sharing project. Eur. Plan. Stud. 2020, 1-21. [CrossRef]

44. Deruelle, T. A tribute to the foot soldiers: European health agencies in the fight against antimicrobial resistance. Health Econ. Policy Law 2021, 16, 23-37. [CrossRef]

45. Sinha, M.K.; Thombare, N.N.; Mondal, B. Subclinical Mastitis in Dairy Animals: Incidence, Economics, and Predisposing Factors. Sci. World J. 2014, 2014, 523984. [CrossRef] [PubMed]

46. Krömker, V.; Leimbach, S. Mastitis treatment-Reduction in antibiotic usage in dairy cows. Reprod. Domest. Anim. 2017, 52, 21-29. [CrossRef] [PubMed]

47. Kumar, N.; Manimaran, A.; Kumaresan, A.; Jeyakumar, S.; Sreela, L.; Mooventhan, P.; Sivaram, M. Mastitis effects on reproductive performance in dairy cattle: A review. Trop. Anim. Health Prod. 2017, 49, 663-673. [CrossRef] [PubMed]

48. Getaneh, A.M.; Gebremedhin, E.Z. Meta-analysis of the prevalence of mastitis and associated risk factors in dairy cattle in Ethiopia. Trop. Anim. Health Prod. 2017, 49, 697-705. [CrossRef]

49. Derakhshani, H.; Fehr, K.B.; Sepehri, S.; Francoz, D.; De Buck, J.; Barkema, H.W.; Plaizier, J.C.; Khafipour, E. Invited review: Microbiota of the bovine udder: Contributing factors and potential implications for udder health and mastitis susceptibility. J. Dairy Sci. 2018, 101, 10605-10625. [CrossRef] [PubMed]

50. Heikkilä, A.-M.; Liski, E.; Pyörälä, S.; Taponen, S. Pathogen-specific production losses in bovine mastitis. J. Dairy Sci. 2018, 101, 9493-9504. [CrossRef] [PubMed]

51. Ashraf, A.; Imran, M. Diagnosis of bovine mastitis: From laboratory to farm. Trop. Anim. Health Prod. 2018, 50, 1193-1202. [CrossRef] [PubMed]

52. Deng, Z.; Koop, G.; Lam, T.; Van Der Lans, I.; Vernooij, J.; Hogeveen, H. Farm-level risk factors for bovine mastitis in Dutch automatic milking dairy herds. J. Dairy Sci. 2019, 102, 4522-4535. [CrossRef]

53. Gomes, F.; Saavedra, M.J.; Henriques, M. Bovine mastitis disease/pathogenicity: Evidence of the potential role of microbial biofilms. Pathog. Dis. 2016, 74, 74. [CrossRef] [PubMed]

54. Ruegg, P.L. A 100-Year Review: Mastitis detection, management, and prevention. J. Dairy Sci. 2017, 100, 10381-10397. [CrossRef] [PubMed]

55. Fair, R.J.; Tor, Y. Antibiotics and Bacterial Resistance in the 21st Century. Perspect. Med. Chem. 2014, 6, 25-64. [CrossRef]

56. Serwecińska, L. Antimicrobials and Antibiotic-Resistant Bacteria: A Risk to the Environment and to Public Health. Water 2020, 12, 3313. [CrossRef]

57. Cerempei, A.; Muresan, E.I.; Cimpoeşu, N.; Carp-Cărare, C.; Rimbu, C.M. Dyeing and antibacterial properties of aqueous extracts from quince (Cydonia oblonga) leaves. Ind. Crop. Prod. 2016, 94, 216-225. [CrossRef]

58. Cristina, R.; Cristina, H.; Petruța, A.; Eleonora, G.; Cătălin, C.-C.; Carmen, C.; Viorel, F.; Mariana, G.; Gabriel, D.; Anca, M. The Antibacterial Activity and Synergies between Morusin and Some Antibiotics against MRSA Strains—Preliminary Study. Sci. Pap. Vet. Med. Iasi Rom. 2017, 61, 39-47.

59. Barbieri, R.; Coppo, E.; Marchese, A.; Daglia, M.; Sobarzo-Sánchez, E.; Nabavi, S.F.; Nabavi, S.M. Phytochemicals for human disease: An update on plant-derived compounds antibacterial activity. Microbiol. Res. 2017, 196, 44-68. [CrossRef]

60. Miron, A.; Aelenei, P.; Trifan, A.; Rimbu, C.M.; Horhogea, C.; Luca, S.; Neagu, A.; Wolfram, E.; Aprotosoaie, A. Plant-derived products as antibiotic enhancers and antibiotic-resistance modifying agents. In Proceedings of the 67th International Congress and Annual Meeting of the Society for Medicinal Plant and Natural Product Research (GA), Innsbruck, Austria, 1-5 September 2019.

61. Aelenei, P.; Luca, S.V.; Horhogea, C.E.; Rimbu, C.M.; Dimitriu, G.; Macovei, I.; Silion, M.; Aprotosoaie, A.C.; Miron, A. Morus alba leaf extract: Metabolite profiling and interactions with antibiotics against Staphylococcus spp. including MRSA. Phytochem. Lett. 2019, 31, 217-224. [CrossRef]

62. Ginovyan, M.; Trchounian, A. Novel approach to combat antibiotic resistance: Evaluation of some Armenian herb crude extracts for their antibiotic modulatory and antiviral properties. J. Appl. Microbiol. 2019, 127, 472-480. [CrossRef]

63. Mahavy, C.E.; Duez, P.; ElJaziri, M.; Rasamiravaka, T. African Plant-Based Natural Products with Antivirulence Activities to the Rescue of Antibiotics. Antibiotics 2020, 9, 830. [CrossRef]

64. Gahamanyi, N.; Song, D.-G.; Cha, K.H.; Yoon, K.-Y.; Mboera, L.E.; Matee, M.I.; Mutangana, D.; Amachawadi, R.G.; Komba, E.V.; Pan, C.-H. Susceptibility of Campylobacter Strains to Selected Natural Products and Frontline Antibiotics. Antibiotics $2020,9,790$. [CrossRef] [PubMed]

65. Cunsolo, V.; Schicchi, R.; Chiaramonte, M.; Inguglia, L.; Arizza, V.; Cusimano, M.; Schillaci, D.; Di Francesco, A.; Saletti, R.; lo Celso, F.; et al. Identification of New Antimicrobial Peptides from Mediterranean Medical Plant Charybdis pancration (Steinh.) Speta. Antibiotics 2020, 9, 747. [CrossRef] [PubMed]

66. Aelenei, P.; Rimbu, C.M.; Horhogea, C.E.; Lobiuc, A.; Neagu, A.-N.; Dunca, S.I.; Motrescu, I.; Dimitriu, G.; Aprotosoaie, A.C.; Miron, A. Prenylated phenolics as promising candidates for combination antibacterial therapy: Morusin and kuwanon G. Saudi Pharm. J. 2020, 28, 1172-1181. [CrossRef] [PubMed]

67. Abu El-Wafa, W.M.; Ahmed, R.H.; Ramadan, M.A.-H. Synergistic effects of pomegranate and rosemary extracts in combination with antibiotics against antibiotic resistance and biofilm formation of Pseudomonas aeruginosa. Braz. J. Microbiol. 2020, 51, 1079-1092. [CrossRef] 
68. Casciaro, B.; Mangiardi, L.; Cappiello, F.; Romeo, I.; Loffredo, M.R.; Iazzetti, A.; Calcaterra, A.; Goggiamani, A.; Ghirga, F.; Mangoni, M.L.; et al. Naturally-Occurring Alkaloids of Plant Origin as Potential Antimicrobials against Antibiotic-Resistant Infections. Molecules 2020, 25, 3619. [CrossRef]

69. Porras, G.; Chassagne, F.; Lyles, J.T.; Marquez, L.; Dettweiler, M.; Salam, A.M.; Samarakoon, T.; Shabih, S.; Farrokhi, D.R.; Quave, C.L. Ethnobotany and the Role of Plant Natural Products in Antibiotic Drug Discovery. Chem. Rev. 2021, 121, 3495-3560. [CrossRef]

70. Kou, J.; Xin, T.Y.; McCarron, P.; Gupta, G.; Dureja, H.; Satija, S.; Mehta, M.; Bakshi, H.A.; Tambuwala, M.M.; Collet, T.; et al. Going Beyond Antibiotics: Natural Plant Extracts as an Emergent Strategy to Combat Biofilm-Associated Infections. J. Environ. Pathol. Toxicol. Oncol. 2020, 39, 125-136. [CrossRef] [PubMed]

71. Sakarikou, C.; Kostoglou, D.; Simões, M.; Giaouris, E. Exploitation of plant extracts and phytochemicals against resistant Salmonella spp. in biofilms. Food Res. Int. 2020, 128, 108806. [CrossRef]

72. Wang, L.; Huang, Y.; Yin, G.; Wang, J.; Wang, P.; Chen, Z.-Y.; Wang, T.; Ren, G. Antimicrobial activities of Asian ginseng, American ginseng, and notoginseng. Phytother. Res. 2020, 34, 1226-1236. [CrossRef]

73. Bouari, C.; Nadăs, G.; Chirilă, F.; Răpuntean, S.; Cătoi, C.; Tăbăran, F.A.; Gal, A.; Taulescu, M.; Fit, N. Prevalence and Antimicrobial Susceptibility Profiles of Pathogens Isolated from Bovine Mastitis Milk in Transylvania. Rom. Bull. Univ. Agric. Sci. Vet. 2016, 73, 329-333. [CrossRef]

74. Patra, J.K.; Das, G.; Fraceto, L.F.; Campos, E.V.R.; del Pilar Rodriguez-Torres, M.; Acosta-Torres, L.S.; Diaz-Torres, L.A.; Grillo, R.; Swamy, M.K.; Sharma, S.; et al. Nano based drug delivery systems: Recent developments and future prospects. J. Nanobiotechnol. 2018, 16, 71. [CrossRef] [PubMed]

75. Moldovan, R.I.; Oprean, R.; Benedec, D.; Hanganu, D.; Duma, M.; Oniga, I.; Vlase, L. LC-MS Analysis, Antioxidant and Antimicrobial Activities for Five Species of Mentha Cultivated in Romania. Dig. J. Nanomater. Biostruct. 2014, 9, 559-566.

76. Bobis, O.; Dezmirean, D.S.; Tomos, L.; Chirila, F.; Marghitas, L.A. Influence of phytochemical profile on antibacterial activity of different medicinal plants against gram-positive and gram-negative bacteria. Appl. Biochem. Microbiol. 2015, 51, 113-118. [CrossRef]

77. Ahmed, S.; Ahmad, M.; Swami, B.L.; Ikram, S. A review on plants extract mediated synthesis of silver nanoparticles for antimicrobial applications: A green expertise. J. Adv. Res. 2016, 7, 17-28. [CrossRef]

78. Pașca, C.; Mărghitaș, L.; Dezmirean, D.; Bobiș, O.; Bonta, V.; Chirilă, F.; Matei, I.; Fiț, N. Medicinal Plants Based Products Tested on Pathogens Isolated from Mastitis Milk. Molecules 2017, 22, 1473. [CrossRef]

79. Burdușel, A.-C.; Gherasim, O.; Grumezescu, A.M.; Mogoantă, L.; Ficai, A.; Andronescu, E. Biomedical Applications of Silver Nanoparticles: An Up-to-Date Overview. Nanomaterials 2018, 8, 681. [CrossRef]

80. Vasile, C.; Baican, M. Progresses in Food Packaging, Food Quality, and Safety-Controlled-Release Antioxidant and/or Antimicrobial Packaging. Molecules 2021, 26, 1263. [CrossRef] [PubMed]

81. Olaru, D.G.; Olaru, A.; Kassem, G.H.; Popescu-Driga, M.V.; Pinosanu, L.R.; Dumitrascu, D.I.; Popescu, E.L.; Hermann, D.M.; Popa-Wagner, A. Toxicity and Health Impact of Nanoparticles. Basic Biology and Clinical Perspective. Rom. J. Morphol. Embryol. 2019, 60, 787-792. [PubMed]

82. Ahmed, T.; Shahid, M.; Noman, M.; Bilal Khan Niazi, M.; Zubair, M.; Almatroudi, A.; Khurshid, M.; Tariq, F.; Mumtaz, R.; Li, B. Bioprospecting a native silver-resistant Bacillus safensis strain for green synthesis and subsequent antibacterial and anticancer activities of silver nanoparticles. J. Adv. Res. 2020, 24, 475-483. [CrossRef] [PubMed]

83. Sánchez-López, E.; Gomes, D.; Esteruelas, G.; Bonilla, L.; Lopez-Machado, A.L.; Galindo, R.; Cano, A.; Espina, M.; Ettcheto, M.; Camins, A.; et al. Metal-Based Nanoparticles as Antimicrobial Agents: An Overview. Nanomaterials 2020, 10, 292. [CrossRef]

84. Zhu, H.; Du, M.; Fox, L.; Zhu, M.-J. Bactericidal effects of Cinnamon cassia oil against bovine mastitis bacterial pathogens. Food Control 2016, 66, 291-299. [CrossRef]

85. Taga, I.; Lan, C.Q.; Altosaar, I. Plant Essential Oils and Mastitis Disease: Their Potential Inhibitory Effects on Pro-inflammatory Cytokine Production in Response to Bacteria Related Inflammation. Nat. Prod. Commun. 2012, 7, 675-682. [CrossRef] [PubMed]

86. Vasconcelos, N.; Croda, J.; Simionatto, S. Antibacterial mechanisms of cinnamon and its constituents: A review. Microb. Pathog. 2018, 120, 198-203. [CrossRef]

87. Nardoni, S.; Ebani, V.V.; D'Ascenzi, C.; Pistelli, L.; Mancianti, F. Sensitivity of Entomopathogenic Fungi and Bacteria to Plants Secondary Metabolites, for an Alternative Control of Rhipicephalus (Boophilus) microplus in Cattle. Front. Pharmacol. 2018, 9, 9. [CrossRef]

88. Abboud, M.; El Rammouz, R.; Jammal, B.; Sleiman, M. In Vitro and In Vivo Antimicrobial Activity of Two Essential Oils Thymus Vulgaris and Lavandula Angustifolia against Bovine Staphylococcus and Streptococcus Mastitis Pathogen. Middle East J. Agric. Res. 2015, 4, 975-983.

89. Ksouri, S.; Djebir, S.; Hadef, Y.; Benakhla, A. Survey of Bovine Mycotic Mastitis in Different Mammary Gland Statuses in Two North-Eastern Regions of Algeria. Mycopathologia 2015, 179, 327-331. [CrossRef]

90. Cerioli, M.F.; Moliva, M.V.; Cariddi, L.N.; Reinoso, E.B. Effect of the Essential Oil of Minthostachys verticillata (Griseb.) Epling and Limonene on Biofilm Production in Pathogens Causing Bovine Mastitis. Front. Vet. Sci. 2018, 5, 146. [CrossRef]

91. Grzesiak, B.; Kołodziej, B.; Głowacka, A.; Krukowski, H. The Effect of Some Natural Essential Oils Against Bovine Mastitis Caused by Prototheca zopfii Isolates In Vitro. Mycopathologia 2018, 183, 541-550. [CrossRef] [PubMed] 
92. De Jesus, G.S.; Micheletti, A.C.; Padilha, R.G.; de Souza de Paula, J.; Alves, F.M.; Leal, C.R.B.; Garcez, F.R.; Garcez, W.S.; Yoshida, N.C. Antimicrobial Potential of Essential Oils from Cerrado Plants against Multidrug-Resistant Foodborne Microorganisms. Molecules 2020, 25, 3296. [CrossRef]

93. Báez-Magaña, M.; Ochoa-Zarzosa, A.; Alva-Murillo, N.; Salgado-Garciglia, R.; López-Meza, J.E. Lipid-Rich Extract from Mexican Avocado Seed (Persea americana var. drymifolia) Reduces Staphylococcus aureus Internalization and Regulates Innate Immune Response in Bovine Mammary Epithelial Cells. J. Immunol. Res. 2019, 2019, 7083491. [CrossRef] [PubMed]

94. Procópio, T.F.; Moura, M.C.; Bento, E.F.L.; Soares, T.; Coelho, L.C.B.B.; Bezerra, R.P.; Mota, R.A.; Porto, A.L.F.; Paiva, P.M.G.; Napoleão, T.H. Looking for alternative treatments for bovine and caprine mastitis: Evaluation of the potential of Calliandra surinamensis leaf pinnulae lectin (CasuL), both alone and in combination with antibiotics. Microbiol. Open 2019, 8, e869. [CrossRef]

95. Gomes, F.; Rodrigues, M.E.; Martins, N.; Ferreira, I.C.; Henriques, M. Phenolic Plant Extracts Versus Penicillin G: In Vitro Susceptibility of Staphylococcus aureus Isolated from Bovine Mastitis. Pharmaceuticals 2019, 12, 128. [CrossRef]

96. Kher, M.N.; Sheth, N.R.; Bhatt, V.D. In Vitro Antibacterial Evaluation of Terminalia chebula as an Alternative of Antibiotics against Bovine Subclinical Mastitis. Anim. Biotechnol. 2019, 30, 151-158. [CrossRef]

97. Mordmuang, A.; Brouillette, E.; Voravuthikunchai, S.P.; Malouin, F. Evaluation of a Rhodomyrtus tomentosa ethanolic extract for its therapeutic potential on Staphylococcus aureus infections using in vitro and in vivo models of mastitis. Vet. Res. 2019, 50, 49. [CrossRef]

98. Sobrinho Santos, E.M.; Almeida, A.C.; Santos, H.O.; Cangussu, A.R.; Costa, K.S.; Alves, J.N.; Bertucci Barbosa, L.C.; Aguiar, R.W.S. Mechanism of Brassica oleracea performance in bovine infectious mastitis by bioinformatic analysis. Microb. Pathog. 2019, 129, 19-29. [CrossRef]

99. Ksouri, S.; Djebir, S.; Bentorki, A.A.; Gouri, A.; Hadef, Y.; Benakhla, A. Antifungal activity of essential oils extract from Origanum floribundum Munby, Rosmarinus officinalis L. and Thymus ciliatus Desf. against Candida albicans isolated from bovine clinical mastitis. J. Mycol. Méd. 2017, 27, 245-249. [CrossRef] [PubMed]

100. Cho, B.-W.; Cha, C.-N.; Lee, S.-M.; Kim, M.-J.; Park, J.-Y.; Yoo, C.-Y.; Son, S.-E.; Kim, S.; Lee, H.-J. Therapeutic effect of oregano essential oil on subclinical bovine mastitis caused by Staphylococcus aureus and Escherichia coli. Korean J. Vet. Res. 2015, 55, 253-257. [CrossRef]

101. Fratini, F.; Casella, S.; Leonardi, M.; Pisseri, F.; Ebani, V.V.; Pistelli, L.; Pistelli, L. Antibacterial activity of essential oils, their blends and mixtures of their main constituents against some strains supporting livestock mastitis. Fitoterapia 2014, 96, 1-7. [CrossRef]

102. Rapuntean, S.; Bolfă, P.F.; Taulescu, M.; Catoi, C. In Vitro Evaluation of the Antimicrobial Properties of Some Plant Essential Oils against Clinical Isolates of Prototheca Spp. Rom. Biotechnol. Lett. 2011, 16, 6146-6152.

103. Lopes, T.S.; Fontoura, P.S.; Oliveira, A.; Rizzo, F.A.; Silveira, S.; Streck, A.F. Use of plant extracts and essential oils in the control of bovine mastitis. Res. Vet. Sci. 2020, 131, 186-193. [CrossRef]

104. Kalińska, A.; Jaworski, S.; Wierzbicki, M.; Gołębiewski, M. Silver and Copper Nanoparticles-An Alternative in Future Mastitis Treatment and Prevention? Int. J. Mol. Sci. 2019, 20, 1672. [CrossRef] [PubMed]

105. Akintelu, S.A.; Bo, Y.; Folorunso, A.S. A Review on Synthesis, Optimization, Mechanism, Characterization, and Antibacterial Application of Silver Nanoparticles Synthesized from Plants. J. Chem. 2020, 2020, 3189043. [CrossRef]

106. Fei Guo, C.; Sun, T.; Cao, F.; Liu, Q.; Ren, Z. Metallic nanostructures for light trapping in energy-harvesting devices. Light Sci. Appl. 2014, 3, e161. [CrossRef]

107. Ghasemzadeh, F.; Esmaeili Shayan, M. Nanotechnology in the Service of Solar Energy Systems. In Nanotechnology and the Environment; IntechOpen: London, UK, 2020.

108. Mousa, M.; Evans, N.D.; Oreffo, R.O.; Dawson, J.I. Clay nanoparticles for regenerative medicine and biomaterial design: A review of clay bioactivity. Biomaterials 2018, 159, 204-214. [CrossRef]

109. Rudramurthy, G.R.; Swamy, M.K. Potential applications of engineered nanoparticles in medicine and biology: An update. JBIC J. Biol. Inorg. Chem. 2018, 23, 1185-1204. [CrossRef]

110. Pöttler, M.; Cicha, I.; Unterweger, H.; Janko, C.; Friedrich, R.P.; Alexiou, C. Nanoparticles for regenerative medicine. Nanomedicine 2019, 14, 1929-1933. [CrossRef]

111. Dadfar, S.M.; Roemhild, K.; Drude, N.I.; von Stillfried, S.; Knüchel, R.; Kiessling, F.; Lammers, T. Iron oxide nanoparticles: Diagnostic, therapeutic and theranostic applications. Adv. Drug Deliv. Rev. 2019, 138, 302-325. [CrossRef] [PubMed]

112. Mitchell, M.J.; Billingsley, M.M.; Haley, R.M.; Wechsler, M.E.; Peppas, N.A.; Langer, R. Engineering precision nanoparticles for drug delivery. Nat. Rev. Drug Discov. 2021, 20, 101-124. [CrossRef] [PubMed]

113. Falchi, L.; Khalil, W.; Hassan, M.; Marei, W.F. Perspectives of nanotechnology in male fertility and sperm function. Int. J. Vet. Sci. Med. 2018, 6, 265-269. [CrossRef] [PubMed]

114. Feugang, J.M.; Rhoads, C.E.; Mustapha, P.A.; Tardif, S.; Parrish, J.J.; Willard, S.T.; Ryan, P.L. Treatment of boar sperm with nanoparticles for improved fertility. Theriogenology 2019, 137, 75-81. [CrossRef]

115. Neculai-Valeanu, A.-S.; Ariton, A. Game-Changing Approaches in Sperm Sex-Sorting: Microfluidics and Nanotechnology. Animals 2021, 11, 1182. [CrossRef]

116. Popa, V.I.; Căpraru, A.-M.; Grama, S.; Măluţan, T. Nanoparticles Based on Modified Lignins with Biocide Properties. Cellul. Chem. Technol. 2011, 45, 221-226.

117. Liang, W.; Yu, A.; Wang, G.; Zheng, F.; Jia, J.; Xu, H. Chitosan-based nanoparticles of avermectin to control pine wood nematodes. Int. J. Biol. Macromol. 2018, 112, 258-263. [CrossRef] 
118. Zikeli, F.; Vinciguerra, V.; D'Annibale, A.; Capitani, D.; Romagnoli, M.; Mugnozza, G.S. Preparation of Lignin Nanoparticles from Wood Waste for Wood Surface Treatment. Nanomaterials 2019, 9, 281. [CrossRef]

119. Motelica, L.; Ficai, D.; Ficai, A.; Truşcă, R.-D.; Ilie, C.-I.; Oprea, O.-C.; Andronescu, E. Innovative Antimicrobial Chitosan/ZnO/Ag NPs/Citronella Essential Oil Nanocomposite-Potential Coating for Grapes. Foods 2020, 9, 1801. [CrossRef]

120. Tan, C.; McClements, D. Application of Advanced Emulsion Technology in the Food Industry: A Review and Critical Evaluation Foods 2021, 10, 812. [CrossRef]

121. Alirezalu, K.; Yaghoubi, M.; Poorsharif, L.; Aminnia, S.; Kahve, H.; Pateiro, M.; Lorenzo, J.; Munekata, P. Antimicrobial PolyamideAlginate Casing Incorporated with Nisin and $\varepsilon$-Polylysine Nanoparticles Combined with Plant Extract for Inactivation of Selected Bacteria in Nitrite-Free Frankfurter-Type Sausage. Foods 2021, 10, 1003. [CrossRef]

122. Medina, J.; Calabi-Floody, M.; Aponte, H.; Santander, C.; Paneque, M.; Meier, S.; Panettieri, M.; Cornejo, P.; Borie, F.; Knicker, H. Utilization of Inorganic Nanoparticles and Biochar as Additives of Agricultural Waste Composting: Effects of End-Products on Plant Growth, $\mathrm{C}$ and Nutrient Stock in Soils from a Mediterranean Region. Agronomy 2021, 11, 767. [CrossRef]

123. Semida, W.; Abdelkhalik, A.; Mohamed, G.; Abd El-Mageed, T.A.; Abd El-Mageed, S.A.; Rady, M.; Ali, E. Foliar Application of Zinc Oxide Nanoparticles Promotes Drought Stress Tolerance in Eggplant (Solanum melongena L.). Plants 2021, 10, 421. [CrossRef]

124. Picchi, V.; Gobbi, S.; Fattizzo, M.; Zefelippo, M.; Faoro, F. Chitosan Nanoparticles Loaded with N-Acetyl Cysteine to Mitigate Ozone and Other Possible Oxidative Stresses in Durum Wheat. Plants 2021, 10, 691. [CrossRef]

125. García-Sánchez, S.; Gala, M.; Žoldák, G. Nanoimpact in Plants: Lessons from the Transcriptome. Plants 2021, 10, 751. [CrossRef] [PubMed]

126. Khalofah, A.; Kilany, M.; Migdadi, H. Phytostimulatory Influence of Comamonas testosteroni and Silver Nanoparticles on Linum usitatissimum L. under Salinity Stress. Plants 2021, 10, 790. [CrossRef] [PubMed]

127. Sawalha, H.; Abiri, R.; Sanusi, R.; Shaharuddin, N.; Noor, A.; Ab Shukor, N.; Abdul-Hamid, H.; Ahmad, S. Toward a Better Understanding of Metal Nanoparticles, a Novel Strategy from Eucalyptus Plants. Plants 2021, 10, 929. [CrossRef]

128. Iravani, S. Methods for Preparation of Metal Nanoparticles. In Metal Nanoparticles; Wiley-VCH Verlag GmbH \& Co. KGaA: Weinheim, Germany, 2017.

129. Singh, J.; Dutta, T.; Kim, K.-H.; Rawat, M.; Samddar, P.; Kumar, P. 'Green' synthesis of metals and their oxide nanoparticles: Applications for environmental remediation. J. Nanobiotechnol. 2018, 16, 84. [CrossRef]

130. Jamkhande, P.G.; Ghule, N.W.; Bamer, A.H.; Kalaskar, M.G. Metal nanoparticles synthesis: An overview on methods of preparation, advantages and disadvantages, and applications. J. Drug Deliv. Sci. Technol. 2019, 53, 53. [CrossRef]

131. Neculai-Văleanu, S.; Ariton, A.-M.; Matei, A.-C.; Mădescu, B.-M.; Davidescu, M.-A.; Poroșnicu, I.; Creangă, Ș. Green Synthesis of Silver Nanoparticles Using Curcuma Longa Plant Extract and Their Possible Applications. In Proceedings of the International Scientific Congress "Life Sciences, A Challenge for The Future", Iași, Romania, 23-25 October 2014; Filodiritto Editore: Iași, Romania, 2019; pp. 288-293.

132. Marinescu, L.; Ficai, D.; Oprea, O.; Marin, A.; Ficai, A.; Andronescu, E.; Holban, A.-M. Optimized Synthesis Approaches of Metal Nanoparticles with Antimicrobial Applications. J. Nanomater. 2020, 2020, 6651207. [CrossRef]

133. Devatha, C.P.; Thalla, A.K. Green Synthesis of Nanomaterials. In Synthesis of Inorganic Nanomaterials; Elsevier: Amsterdam, The Netherlands, 2018.

134. Noah, N. Green synthesis: Characterization and application of silver and gold nanoparticles. In Green Synthesis, Characterization and Applications of Nanoparticles; Elsevier: Amsterdam, The Netherlands, 2019.

135. Cele, T. Preparation of Nanoparticles. In Engineered Nanomaterials_Health and Safety; IntechOpen: London, UK, 2020.

136. Raj, S.; Mali, S.C.; Trivedi, R. Green synthesis and characterization of silver nanoparticles using Enicostemma axillare (Lam.) leaf extract. Biochem. Biophys. Res. Commun. 2018, 503, 2814-2819. [CrossRef] [PubMed]

137. Das, P.E.; Abu-Yousef, I.A.; Majdalawieh, A.F.; Narasimhan, S.; Poltronieri, P. Green Synthesis of Encapsulated Copper Nanoparticles Using a Hydroalcoholic Extract of Moringa oleifera Leaves and Assessment of Their Antioxidant and Antimicrobial Activities. Molecules 2020, 25, 555. [CrossRef]

138. Kamath, V.; Chandra, P.; Jeppu, G.P. Comparative study of using five different leaf extracts in the green synthesis of iron oxide nanoparticles for removal of arsenic from water. Int. J. Phytoremediat. 2020, 22, 1278-1294. [CrossRef] [PubMed]

139. Muthu, K.; Priya, S. Green synthesis, characterization and catalytic activity of silver nanoparticles using Cassia auriculata flower extract separated fraction. Spectrochim. Acta Part A Mol. Biomol. Spectrosc. 2017, 179, 66-72. [CrossRef] [PubMed]

140. Kumar, H.; Bhardwaj, K.; Kuča, K.; Kalia, A.; Nepovimova, E.; Verma, R.; Kumar, D. Flower-Based Green Synthesis of Metallic Nanoparticles: Applications beyond Fragrance. Nanomaterials 2020, 10, 766. [CrossRef]

141. AlSalhi, M.S.; Devanesan, S.; Alfuraydi, A.A.; Vishnubalaji, R.; Munusamy, M.A.; Murugan, K.; Nicoletti, M.; Benelli, G. Green synthesis of silver nanoparticles using Pimpinella anisum seeds: Antimicrobial activity and cytotoxicity on human neonatal skin stromal cells and colon cancer cells. Int. J. Nanomed. 2016, 11, 4439-4449. [CrossRef]

142. Deshmukh, A.R.; Gupta, A.; Kim, B.S. Ultrasound Assisted Green Synthesis of Silver and Iron Oxide Nanoparticles Using Fenugreek Seed Extract and Their Enhanced Antibacterial and Antioxidant Activities. BioMed Res. Int. 2019, $2019,1714358$. [CrossRef]

143. Yuan, C.; Huo, C.; Gui, B.; Cao, W. Green synthesis of gold nanoparticles using Citrus maxima peel extract and their catalytic/antibacterial activities. IET Nanobiotechnol. 2017, 11, 523-530. [CrossRef] 
144. Tan Sian Hui Abdullah, H.S.; Aqlili Riana Mohd Asseri, S.N.; Khursyiah Wan Mohamad, W.N.; Kan, S.-Y.; Azmi, A.A.; Yong Julius, F.S.; Chia, P.W. Green synthesis, characterization and applications of silver nanoparticle mediated by the aqueous extract of red onion peel. Environ. Pollut. 2021, 271, 116295. [CrossRef]

145. Behravan, M.; Panahi, A.H.; NaghiZadeh, A.; Ziaee, M.; Mahdavi, R.; Mirzapour, A. Facile green synthesis of silver nanoparticles using Berberis vulgaris leaf and root aqueous extract and its antibacterial activity. Int. J. Biol. Macromol. 2019, 124, 148-154. [CrossRef]

146. Sharifi-Rad, M.; Pohl, P.; Epifano, F.; Álvarez-Suarez, J.M. Green Synthesis of Silver Nanoparticles Using Astragalus tribuloides Delile. Root Extract: Characterization, Antioxidant, Antibacterial, and Anti-Inflammatory Activities. Nanomaterials 2020, 10, 2383. [CrossRef]

147. Sinsinwar, S.; Sarkar, M.K.; Suriya, K.R.; Nithyanand, P.; Vadivel, V. Use of agricultural waste (coconut shell) for the synthesis of silver nanoparticles and evaluation of their antibacterial activity against selected human pathogens. Microb. Pathog. 2018, 124, 30-37. [CrossRef]

148. Neculai-Valeanu, A.S.; Ariton, A.M.; Madescu, B.; Ghe, V.; Creanga, S. Harnessing Agri-Waste for Green Synthesis of Silver Nanoparticles. In Proceedings of the ISB-INMA TEH' 2020 Proceedings, Bucharest, Romania, 30 October 2020; pp. $172-175$.

149. Vasyliev, G.; Vorobyova, V.; Skiba, M.; Khrokalo, L. Green Synthesis of Silver Nanoparticles Using Waste Products (Apricot and Black Currant Pomace) Aqueous Extracts and Their Characterization. Adv. Mater. Sci. Eng. 2020, 2020, 4505787. [CrossRef]

150. Okpara, E.C.; Fayemi, O.E.; Sherif, E.-S.M.; Junaedi, H.; Ebenso, E.E. Green Wastes Mediated Zinc Oxide Nanoparticles: Synthesis, Characterization and Electrochemical Studies. Materials 2020, 13, 4241. [CrossRef]

151. Bedlovičová, Z.; Salayová, A. Green-Synthesized Silver Nanoparticles and Their Potential for Antibacterial Applications. In Bacterial Pathogenesis and Antibacterial Control; InTech: London, UK, 2018.

152. Mousavi, S.M.; Hashemi, S.A.; Ghasemi, Y.; Atapour, A.; Amani, A.M.; Savar Dashtaki, A.; Babapoor, A.; Arjmand, O. Green synthesis of silver nanoparticles toward bio and medical applications: Review study. Artif. Cells Nanomed. Biotechnol. 2018, 46, S855-S872. [CrossRef]

153. Ogunyemi, S.O.; Abdallah, Y.; Zhang, M.; Fouad, H.; Hong, X.; Ibrahim, E.; Masum, M.I.; Hossain, A.; Mo, J.; Li, B. Green synthesis of zinc oxide nanoparticles using different plant extracts and their antibacterial activity against Xanthomonas oryzae pv. oryzae. Artif. Cells Nanomed. Biotechnol. 2019, 47, 341-352. [CrossRef]

154. El-Sherbiny, I.M.; Sedki, M. Green Synthesis of Chitosan-Silver/Gold Hybrid Nanoparticles for Biomedical Applications. Breast Cancer 2019, 2000, 79-84. [CrossRef]

155. Ibrahim, S.; Ahmad, Z.; Manzoor, M.Z.; Mujahid, M.; Faheem, Z.; Adnan, A. Optimization for biogenic microbial synthesis of silver nanoparticles through response surface methodology, characterization, their antimicrobial, antioxidant, and catalytic potential. Sci. Rep. 2021, 11, 770. [CrossRef]

156. Ekaji, F.A.; Akujobi, C.O.; Umeh, S.I. Optimization of Selected Process Parameters Affecting Yield of Green Synthesized Silver Nanoparticles and Their Antibacterial Activity. Biotechnol. J. Int. 2021, 25, 25-36. [CrossRef]

157. Wady, A.F.; Machado, A.L.; Foggi, C.C.; Zamperini, C.A.; Zucolotto, V.; Moffa, E.B.; Vergani, C.E. Effect of a Silver Nanoparticles Solution onStaphylococcus aureusandCandidaspp. J. Nanomater. 2014, 2014, 545279. [CrossRef]

158. Mocan, L.; Matea, C.; Tabaran, F.A.; Mosteanu, O.; Pop, T.; Puia, C.; Agoston-Coldea, L.; Gonciar, D.; Kalman, E.; Zaharie, G.; et al. Selective in vitro photothermal nano-therapy of MRSA infections mediated by IgG conjugated gold nanoparticles. Sci. Rep. 2016, 6, 39466. [CrossRef]

159. Hibbitts, A.; O'Leary, C. Emerging Nanomedicine Therapies to Counter the Rise of Methicillin-Resistant Staphylococcus aureus. Materials 2018, 11, 321. [CrossRef] [PubMed]

160. Abd El-Aziz, N.K.; Ammar, A.M.; El-Naenaeey, E.-S.Y.M.; El Damaty, H.M.; Elazazy, A.A.; Hefny, A.A.; Shaker, A.; Eldesoukey, I.E. Antimicrobial and antibiofilm potentials of cinnamon oil and silver nanoparticles against Streptococcus agalactiae isolated from bovine mastitis: New avenues for countering resistance. BMC Vet. Res. 2021, 17, 136. [CrossRef]

161. Orellano, M.S.S.; Bohl, L.P.; Breser, M.L.; Isaac, P.; Falcone, R.D.; Porporatto, C. A comparative study of antimicrobial activity of differently-synthesized chitosan nanoparticles against bovine mastitis pathogens. Soft Matter 2021, 17, 694-703. [CrossRef]

162. Aguayo, P.R.; Larenas, T.B.; Godoy, C.A.; Rivas, B.C.; González-Casanova, J.; Rojas-Gómez, D.; Fuentes, N.C. Antimicrobial and Antibiofilm Capacity of Chitosan Nanoparticles against Wild Type Strain of Pseudomonas sp. Isolated from Milk of Cows Diagnosed with Bovine Mastitis. Antibiotics 2020, 9, 551. [CrossRef]

163. Orellano, M.S.; Isaac, P.; Breser, M.L.; Bohl, L.P.; Conesa, A.; Falcone, R.D.; Porporatto, C. Chitosan nanoparticles enhance the antibacterial activity of the native polymer against bovine mastitis pathogens. Carbohydr. Polym. 2019, 213, 1-9. [CrossRef]

164. Hozyen, H.F.; Ibrahim, E.S.; Khairy, E.A.; El-Dek, S.I. Enhanced antibacterial activity of capped zinc oxide nanoparticles: A step towards the control of clinical bovine mastitis. Vet. World 2019, 12, 1225-1232. [CrossRef]

165. Yu, L.; Shang, F.; Chen, X.; Ni, J.; Yu, L.; Zhang, M.; Sun, D.; Xue, T. The anti-biofilm effect of silver-nanoparticle-decorated quercetin nanoparticles on a multi-drug resistant Escherichia coli strain isolated from a dairy cow with mastitis. PeerJ 2018, 6, e5711. [CrossRef]

166. Omara, S.T. MIC and MBC of Honey and Gold Nanoparticles against methicillin-resistant (MRSA) and vancomycin-resistant (VRSA) coagulase-positive S. aureus isolated from contagious bovine clinical mastitis. J. Genet. Eng. Biotechnol. 2017, 15, 219-230. [CrossRef]

167. Sankar, P. New Therapeutic Strategies to Control and Treatment of Bovine Mastitis. Vet. Med. Open J. 2016, 1, e7-e8. [CrossRef] 
168. Machado, G.T.P.; Veleirinho, M.B.; Mazzarino, L.; Filho, L.C.P.M.; Maraschin, M.; Cerri, R.L.A.; Kuhnen, S. Development of propolis nanoparticles for the treatment of bovine mastitis: In vitro studies on antimicrobial and cytotoxic activities. Can. J. Anim. Sci. 2019, 99, 713-723. [CrossRef]

169. Seven, P.T.; Seven, I.; Baykalir, B.G.; Mutlu, S.I.; Salem, A.Z.M. Nanotechnology and nano-propolis in animal production and health: An overview. Ital. J. Anim. Sci. 2018, 17, 921-930. [CrossRef]

170. Kazemi, F.; Divsalar, A.; Saboury, A.A.; Seyedarabi, A. Propolis nanoparticles prevent structural changes in human hemoglobin during glycation and fructation. Colloids Surf. B Biointerfaces 2019, 177, 188-195. [CrossRef] [PubMed]

171. El Hamid, H.M.A.; Abdel-Aziz, M.S.; Abu Naeem, F.M. Antimicrobial Efficacy of Nanopropolis Coated Vs Silver-Curcumin Nanoparticles Coated Gutta-Percha Points on Various Microbial Species. A Comparative In Vitro Study. Egypt. Dent. J. 2020, 66, 1893-1902. [CrossRef]

172. Seven, P.T.; Seven, I.; Karakus, S.; Mutlu, S.I.; Arkali, G.; Sahin, Y.M.; Kilislioglu, A. Turkish Propolis and Its Nano Form Can Ameliorate the Side Effects of Cisplatin, Which Is a Widely Used Drug in the Treatment of Cancer. Plants 2020, 9, 1075. [CrossRef] [PubMed]

173. Soni, G.; Yadav, K.S. Nanogels as potential nanomedicine carrier for treatment of cancer: A mini review of the state of the art. Saudi Pharm. J. 2016, 24, 133-139. [CrossRef]

174. Krishna, A.N.; Reddy, M.V.Y.; Reddy, M.C.B.; Padmini, I. Formulation, Evaluation of Nano Copper Gel for Treatment of Clinical Mastitis. J. Pharmacol. Res. 2017, 11, 547-554.

175. Mohsenabadi, N.; Rajaei, A.; Tabatabaei, M.; Mohsenifar, A. Physical and Antimicrobial Properties of Starch-Carboxy Methyl Cellulose Film Containing Rosemary Essential Oils Encapsulated in Chitosan Nanogel. Int. J. Biol. Macromol. 2018, 112, 148-155. [CrossRef] [PubMed]

176. Vasile, C.; Pamfil, D.; Stoleru, E.; Baican, M. New Developments in Medical Applications of Hybrid Hydrogels Containing Natural Polymers. Molecules 2020, 25, 1539. [CrossRef] [PubMed]

177. Nguyen, V.H. Recent Advances in Experimental Basic Research on Graphene and Graphene-Based Nanostructures. Adv. Nat. Sci. Nanosci. Nanotechnol. 2016, 7, 023001. [CrossRef]

178. Xia, M.-Y.; Xie, Y.; Yu, C.-H.; Chen, G.-Y.; Li, Y.-H.; Zhang, T.; Peng, Q. Graphene-based nanomaterials: The promising active agents for antibiotics-independent antibacterial applications. J. Control. Release 2019, 307, 16-31. [CrossRef]

179. Teodorescu, F.; Quéniat, G.; Foulon, C.; Lecoeur, M.; Barras, A.; Boulahneche, S.; Medjram, M.S.; Hubert, T.; Abderrahmani, A.; Boukherroub, R.; et al. Transdermal skin patch based on reduced graphene oxide: A new approach for photothermal triggered permeation of ondansetron across porcine skin. J. Control. Release 2017, 245, 137-146. [CrossRef] [PubMed]

180. Mohammed, H.; Kumar, A.; Bekyarova, E.; Al-Hadeethi, Y.; Zhang, X.; Chen, M.; Ansari, M.S.; Cochis, A.; Rimondini, L. Antimicrobial Mechanisms and Effectiveness of Graphene and Graphene-Functionalized Biomaterials. A Scope Review. Front. Bioeng. Biotechnol. 2020, 8, 8. [CrossRef]

181. Prasad, K.; Lekshmi, G.S.; Ostrikov, K.; Lussini, V.; Blinco, J.; Mohandas, M.; Vasilev, K.; Bottle, S.; Bazaka, K.; Ostrikov, K. Synergic bactericidal effects of reduced graphene oxide and silver nanoparticles against Gram-positive and Gram-negative bacteria. Sci. Rep. 2017, 7, 1591. [CrossRef] [PubMed]

182. El-Shafai, N.; El-Khouly, M.E.; El-Kemary, M.; Ramadan, M.; Eldesoukey, I.; Masoud, M. Graphene oxide decorated with zinc oxide nanoflower, silver and titanium dioxide nanoparticles: Fabrication, characterization, DNA interaction, and antibacterial activity. RSC Adv. 2019, 9, 3704-3714. [CrossRef]

183. Arfat, Y.A.; Ahmed, J.; Ejaz, M.; Mullah, M. Polylactide/graphene oxide nanosheets/clove essential oil composite films for potential food packaging applications. Int. J. Biol. Macromol. 2018, 107, 194-203. [CrossRef]

184. De Moraes, A.C.M.; Lima, B.A.; de Faria, A.F.; Brocchi, M.; Alves, O.L. Graphene oxide-silver nanocomposite as a promising biocidal agent against methicillin-resistant Staphylococcus aureus. Int. J. Nanomed. 2015, 10, 6847-6861. [CrossRef]

185. Yousefi, M.; Dadashpour, M.; Hejazi, M.; Hasanzadeh, M.; Behnam, B.; de la Guardia, M.; Shadjou, N.; Mokhtarzadeh, A. Anti-bacterial activity of graphene oxide as a new weapon nanomaterial to combat multidrug-resistance bacteria. Mater. Sci. Eng. C 2017, 74, 568-581. [CrossRef] [PubMed]

186. Jaworski, S.; Wierzbicki, M.; Sawosz, E.; Jung, A.; Gielerak, G.; Biernat, J.; Jaremek, H.; Łojkowski, W.; Woźniak, B.; Wojnarowicz, J.; et al. Graphene Oxide-Based Nanocomposites Decorated with Silver Nanoparticles as an Antibacterial Agent. Nanoscale Res. Lett. 2018, 13, 116. [CrossRef] [PubMed]

187. Bugli, F.; Cacaci, M.; Palmieri, V.; Di Santo, R.; Torelli, R.; Ciasca, G.; Di Vito, M.; Vitali, A.; Conti, C.; Sanguinetti, M.; et al. Curcumin-loaded graphene oxide flakes as an effective antibacterial system against methicillin-resistant Staphylococcus aureus. Interface Focus 2018, 8, 20170059. [CrossRef]

188. Shin, Y.C.; Lee, J.H.; Jin, L.; Kim, M.J.; Kim, Y.-J.; Hyun, J.K.; Jung, T.-G.; Hong, S.W.; Han, D.-W. Stimulated myoblast differentiation on graphene oxide-impregnated PLGA-collagen hybrid fibre matrices. J. Nanobiotechnol. 2015, 13, 21. [CrossRef]

189. Vijaya Sekhar, K.; Debroy, S.; Miriyala, V.P.K.; Acharyya, S.G.; Acharyya, A. Self-Healing Phenomena of Graphene: Potential and Applications. Open Phys. 2016, 14, 364-370. [CrossRef]

190. Liao, C.; Li, Y.; Tjong, S.C. Graphene Nanomaterials: Synthesis, Biocompatibility, and Cytotoxicity. Int. J. Mol. Sci. 2018, $19,3564$. [CrossRef] 
191. Lasocka, I.; Jastrzębska, E.; Szulc-Dabrowska, L.; Skibniewski, M.; Pasternak, I.; Hubalek Kalbacova, M.; Skibniewska, E.M. The effects of graphene and mesenchymal stem cells in cutaneous wound healing and their putative action mechanism. Int. J. Nanomed. 2019, 14, 2281-2299. [CrossRef] [PubMed]

192. Pelin, M.; Fusco, L.; León, V.; Martín, C.; Criado, A.; Sosa, S.; Vázquez, E.; Tubaro, A.; Prato, M. Differential cytotoxic effects of graphene and graphene oxide on skin keratinocytes. Sci. Rep. 2017, 7, 40572. [CrossRef]

193. Goyal, A.K.; Singh, R.; Chauhan, G.; Rath, G. Non-invasive systemic drug delivery through mucosal routes. Artif. Cells Nanomed. Biotechnol. 2018, 46, 539-551. [CrossRef] [PubMed]

194. Ways, T.M.M.; Ng, K.W.; Lau, W.M.; Khutoryanskiy, V.V. Silica Nanoparticles in Transmucosal Drug Delivery. Pharmaceutics 2020, 12, 751. [CrossRef]

195. Vllasaliu, D. Non-Invasive Drug Delivery Systems. Pharmaceutics 2021, 13, 611. [CrossRef]

196. Singhal, M.; Lapteva, M.; Kalia, Y.N. Formulation challenges for 21st century topical and transdermal delivery systems. Expert Opin. Drug Deliv. 2017, 14, 705-708. [CrossRef]

197. Boldeanu, L.; Boldeanu, M.V.; Bogdan, M.; Meca, A.D.; Coman, C.G.; Buca, B.R.; Tartau, C.G.; Tartau, L.M. Immunological approaches and therapy in burns (Review). Exp. Ther. Med. 2020, 20, 2361-2367. [CrossRef] [PubMed]

198. Iftime, M.-M.; Tartau, L.M.; Marin, L. New formulations based on salicyl-imine-chitosan hydrogels for prolonged drug release. Int. J. Biol. Macromol. 2020, 160, 398-408. [CrossRef] [PubMed]

199. Ailincai, D.; Mititelu, L.T.; Marin, L. Drug delivery systems based on biocompatible imino-chitosan hydrogels for local anticancer therapy. Drug Deliv. 2018, 25, 1080-1090. [CrossRef] [PubMed]

200. Ailincai, D.; Porzio, W.; Marin, L. Hydrogels Based on Imino-Chitosan Amphiphiles as a Matrix for Drug Delivery Systems. Polymers 2020, 12, 2687. [CrossRef]

201. Mao, K.-L.; Fan, Z.-L.; Yuan, J.-D.; Chen, P.-P.; Yang, J.-J.; Xu, J.; ZhuGe, D.-L.; Jin, B.-H.; Zhu, Q.-Y.; Shen, B.-X.; et al. Skinpenetrating polymeric nanoparticles incorporated in silk fibroin hydrogel for topical delivery of curcumin to improve its therapeutic effect on psoriasis mouse model. Colloids Surf. B Biointerfaces 2017, 160, 704-714. [CrossRef] [PubMed]

202. Ozkahraman, B.; Emeriewen, K.; Saleh, G.M.; Thanh, N.T.K. Engineering hydrogel nanoparticles to enhance transdermal local anaesthetic delivery in human eyelid skin. RSC Adv. 2020, 10, 3926-3930. [CrossRef]

203. Bashyal, S.; Shin, C.Y.; Hyun, S.M.; Jang, S.W.; Lee, S. Preparation, Characterization, and In Vivo Pharmacokinetic Evaluation of Polyvinyl Alcohol and Polyvinyl Pyrrolidone Blended Hydrogels for Transdermal Delivery of Donepezil HCl. Pharmaceutics 2020, 12, 270. [CrossRef]

204. Jacob, S.; Nair, A.; Shah, J.; Sreeharsha, N.; Gupta, S.; Shinu, P. Emerging Role of Hydrogels in Drug Delivery Systems, Tissue Engineering and Wound Management. Pharmaceutics 2021, 13, 357. [CrossRef]

205. Stan, D.; Tanase, C.; Avram, M.; Apetrei, R.; Mincu, N.; Mateescu, A.L. Wound healing applications of creams and "smart" hydrogels. Exp. Dermatol. 2021. [CrossRef]

206. Biondi, M.; Borzacchiello, A.; Mayol, L.; Ambrosio, L. Nanoparticle-Integrated Hydrogels as Multifunctional Composite Materials for Biomedical Applications. Gels 2015, 1, 162-178. [CrossRef]

207. Rafieian, S.; Mirzadeh, H.; Mahdavi, H.; Masoumi, M.E. A review on nanocomposite hydrogels and their biomedical applications. Sci. Eng. Compos. Mater. 2019, 26, 154-174. [CrossRef]

208. Arno, M.C.; Inam, M.; Weems, A.C.; Li, Z.; Binch, A.L.A.; Platt, C.I.; Richardson, S.M.; Hoyland, J.A.; Dove, A.P.; O’Reilly, R.K. Exploiting the role of nanoparticle shape in enhancing hydrogel adhesive and mechanical properties. Nat. Commun. 2020, 11, 1420. [CrossRef] [PubMed]

209. Dai, T.; Wang, C.; Wang, Y.; Xu, W.; Hu, J.; Cheng, Y. A Nanocomposite Hydrogel with Potent and Broad-Spectrum Antibacterial Activity. ACS Appl. Mater. Interfaces 2018, 10, 15163-15173. [CrossRef]

210. Monerris, M.; Broglia, M.F.; Yslas, E.I.; Barbero, C.A.; Rivarola, C.R. Highly effective antimicrobial nanocomposites based on hydrogel matrix and silver nanoparticles: Long-lasting bactericidal and bacteriostatic effects. Soft Matter 2019, 15, 8059-8066. [CrossRef] [PubMed]

211. Helmiyati, N.G.; Abbas, G.H.; Budianto, E. Nanocomposite hydrogel-based biopolymer modified with silver nanoparticles as an antibacterial material for wound treatment. J. Appl. Pharm. Sci. 2019, 9, 1-9. [CrossRef]

212. El-Hady, M.M.A.; Saeed, S.E.-S. Antibacterial Properties and pH Sensitive Swelling of Insitu Formed Silver-Curcumin Nanocomposite Based Chitosan Hydrogel. Polymers 2020, 12, 2451. [CrossRef]

213. Kumar, P.; Huo, P.; Zhang, R.; Liu, B. Antibacterial Properties of Graphene-Based Nanomaterials. Nanomaterials 2019,9 , 737. [CrossRef] [PubMed]

214. Aunkor, T.H.; Raihan, T.; Prodhan, S.H.; Metselaar, H.S.C.; Malik, S.U.F.; Azad, A.K. Antibacterial activity of graphene oxide nanosheet against multidrug resistant superbugs isolated from infected patients. R. Soc. Open Sci. 2020, 7, 200640. [CrossRef] 